\title{
Insights into the role of paraoxonase 2 in human pathophysiology
}

\author{
Fauzia Parween and Rinkoo Devi Gupta* \\ Faculty of Life Sciences and Biotechnology, South Asian University, New Delhi, India \\ *Corresponding author (Email, rdgupta@sau.ac.in)
}

MS received 30 October 2020; accepted 10 November 2021

\begin{abstract}
Paraoxonase 2 (PON2) is a ubiquitously expressed intracellular enzyme that is known to have a protective role from oxidative stress. Clinical studies have also demonstrated the significance of PON2 in the manifestation of cardiovascular and several other diseases, and hence, it is considered an important biomarker. Recent findings of its expression in brain tissue suggest its potential protective effect on oxidative stress and neuroinflammation. Polymorphisms of PON2 in humans are a risk factor in many pathological conditions, suggesting a possible mechanism of its anti-oxidative property probably through lactonase activity. However, exogenous factors may also modulate the expression and activity of PON2. Hence, this review aims to report the mechanism by which PON2 expression is regulated and its role in oxidative stress disorders such as neurodegeneration and tumor formation. The role of PON2 owing to its lactonase activity in bacterial infectious diseases and association of PON2 polymorphism with pathological conditions are also highlighted.
\end{abstract}

Keywords. Anti-oxidative; Lactonase; PON2 expression; PON2 modulators; PON2 polymorphism; Paraoxonase

\begin{abstract}
Abbreviations: AD, Alzheimer's disease; Akt, Protein kinase B; AP-1, Activator protein 1; AMPK, AMPactivated protein kinase; ATF4, Activating transcription factor 4; ATF6, Activating transcription factor 6; BiP, Binding immunoglobulin protein; CHOP, C/EBP homologous protein; CVD, Cardiovascular disease; Cyt C, Cytochrome C; eIF2a, Eukaryotic translation initiation factor 2a; FOXO3a, Forkhead transcription factor; GLUT1, Glucose transporter 1; GSK3 $\beta$, Glycogen synthase kinase 3beta; HS, Homoserine; HSL, Homoserine lactone; IM, Inner membrane; IRE, Iron responsive element; JNK, C-Jun N-terminal kinase; mPTP, Mitochondria permeability transition pore; OM, Outer membrane; PERK, Protein kinase RNA-like endoplasmic reticulum kinase; PI3K, Phosphoionositide 3-kinase; PUMA, P53 upregulated modulator of apoptosis; RISK, Reperfusion injury salvage kinase; STOM, Stomatin; XBP1, X-box binding protein 1.
\end{abstract}

\section{Introduction}

The paraoxonases PON1, PON2, and PON3 are members of esterase family enzymes and are highly conserved within and between species (figure 1) (Teiber et al. 2018). Phylogenetic analysis has revealed that PON2 is the oldest member of the PON family and that PON1 and PON3 have evolved from it (figure 2) (Draganov and $\mathrm{La} \mathrm{Du}$ 2004). The genes of all the three paraoxonases are located next to each other on the long arm of chromosome 7 in the case of humans, and on chromosome 6 in mice (She et al. 2012). PON1 and PON3 are primarily expressed in the liver, and get associated with high density lipoprotein (HDL), whereas PON2 is ubiquitously expressed and is not present in the blood plasma $(\mathrm{Ng}$ et al. 2001; Kulka 2016). PON2 has been detected in several tissues at mRNA level, protein level, or both, including the brain where the other two PONs are not expressed (Costa et al 2014; Ng et al. 2001; Giordano et al. 2011). The highest levels of PON2 are expressed in the lungs and small intestine, followed by the heart and liver, whereas lower levels are reported in testis, kidney, and brain (Marsillach et al. 2008). Although the name 'PON' suggests 


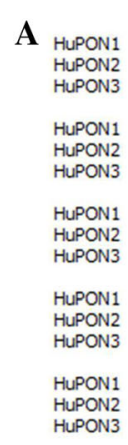

B

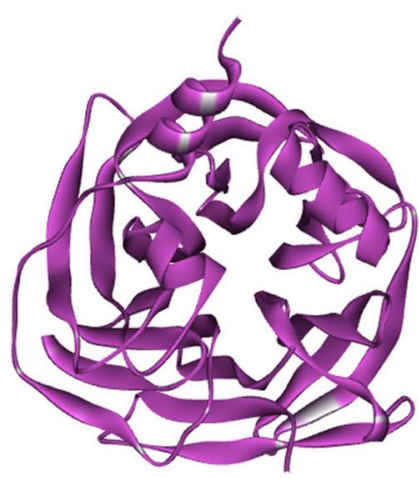

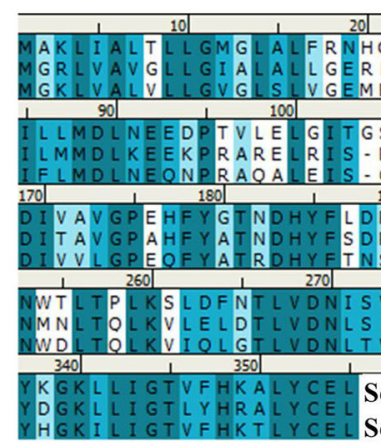

C

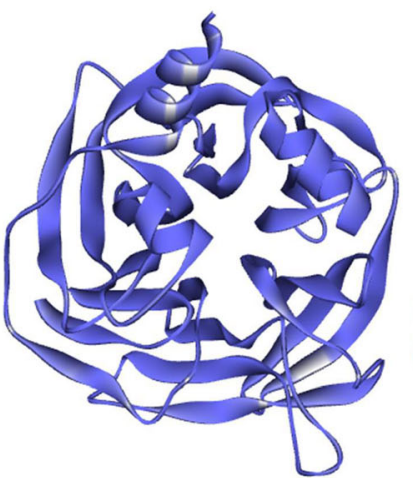

D

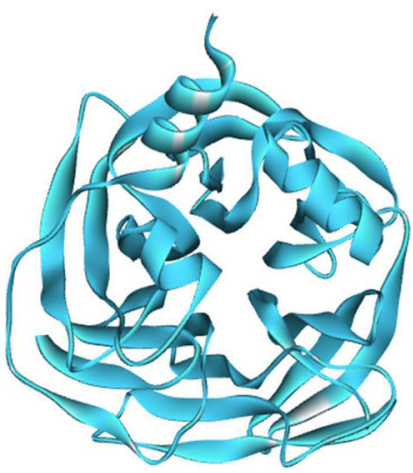

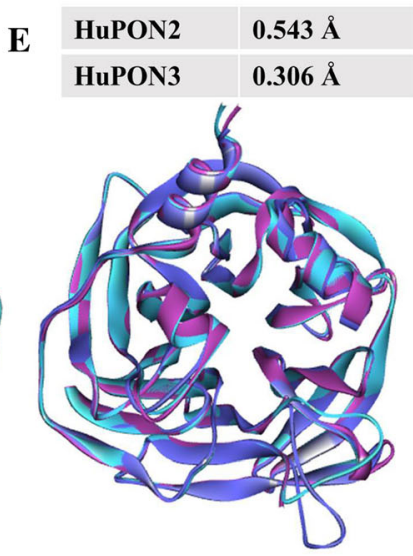

Figure 1. Comparative in silico analysis of human paraoxonases. (A) Sequence alignment of HuPON2 and HuPON3 with Chi-PON1 (PDB:1V04) shows 52.4\% sequence identity and 76.3\% sequence similarity. (B) Crystal structure of HuPON1 (PDB:1V04); magenta color-coded. (C) Homology model of HuPON2, prepared from HuPON1 template (PDB:1V04); blue color-coded. (D) Homology model of HuPON3, prepared from HuPON1 template (PDB:1V04); cyan color-coded. (E) Superimposition of HuPON1 (magenta), HuPON2 (blue), and HuPON3 (cyan), shows the close similarity of all the structures, RMSD values are mentioned in the table. The analysis was performed in Discovery Studio 4.0.

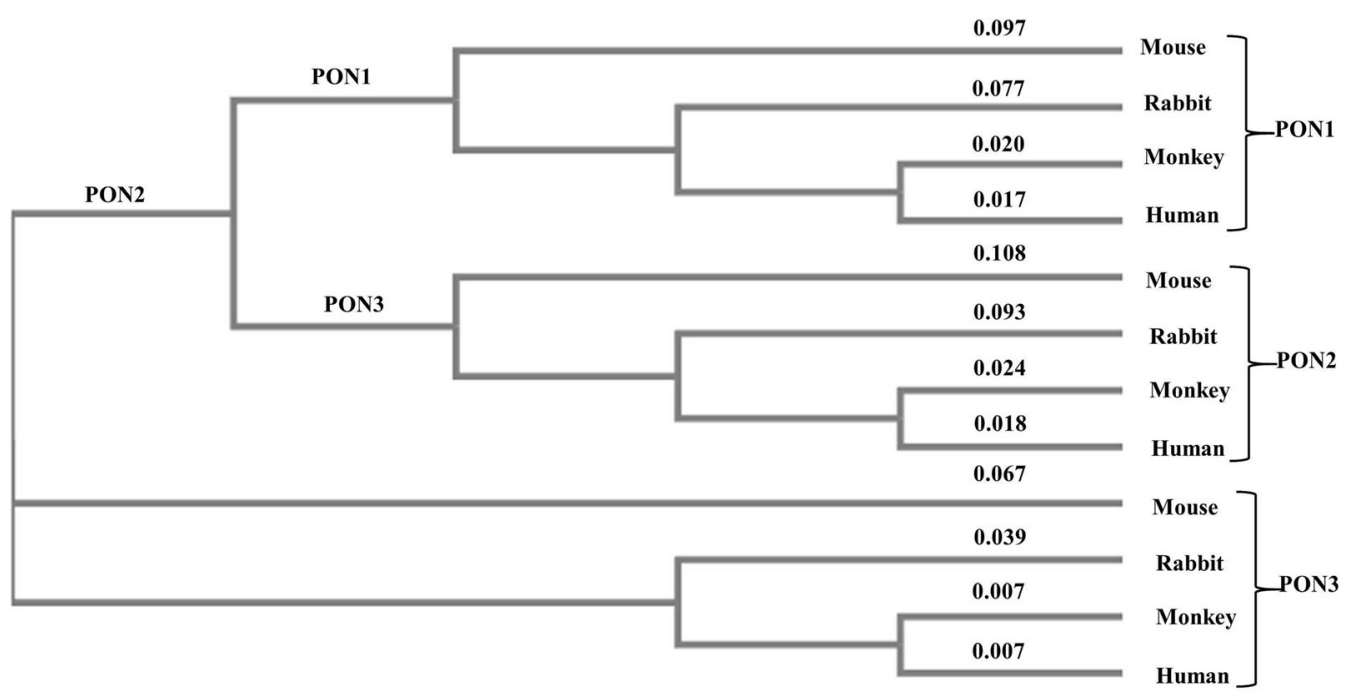

Figure 2. Phylogenetic tree showing the evolutionary origin of human paraoxonases. Four mammals were selected randomly, and their sequences were retrieved from NCBI. Sequence alignment and phylogenetic tree construction were done by using Clustal Omega. The scores on the tree correspond to the evolutionary distance between the sequences. 
Table 1. Comparison of human PON family members

\begin{tabular}{|c|c|c|c|c|}
\hline & PON1 & PON2 & PON3 & References \\
\hline Gene ID & 5444 & 5445 & 5446 & Primo-Parmo et al. (1996) \\
\hline Location & $7 q 21.3$ & & & \\
\hline $\begin{array}{l}\text { Number of amino } \\
\text { acids }\end{array}$ & 355 & 354 & 354 & Taler-Verčič et al. (2020) \\
\hline $\begin{array}{l}\text { Subcellular } \\
\text { expression }\end{array}$ & $\begin{array}{l}\text { Mainly bound to } \\
\text { HDLs in blood } \\
\text { plasma }\end{array}$ & $\begin{array}{l}\text { Present on the } \\
\text { membrane of } \\
\text { mitochondria, on the } \\
\text { ER and on the } \\
\text { plasma membrane }\end{array}$ & $\begin{array}{l}\text { Mainly bound to } \\
\text { HDLs in blood } \\
\text { plasma and } \\
\text { mitochondria }\end{array}$ & $\begin{array}{l}\text { Horke et al. (2008), Devarajan } \\
\text { et al. (2011), Schweikert et al. } \\
\text { (2012a), Hagmann et al. } \\
\text { (2014) }\end{array}$ \\
\hline \multicolumn{5}{|c|}{ Tissue specific expression } \\
\hline mRNA level & $\begin{array}{l}\text { Mostly enriched in } \\
\text { liver with some } \\
\text { small amount in } \\
\text { thymus and adrenal } \\
\text { gland }\end{array}$ & $\begin{array}{l}\text { Enhanced in liver and } \\
\text { distributed in almost } \\
\text { all other tissues }\end{array}$ & $\begin{array}{l}\text { Enriched in liver and } \\
\text { detected in small } \\
\text { amount in many } \\
\text { other tissues }\end{array}$ & $\begin{array}{l}\text { "Tissue expression of PON1 - } \\
\text { Summary - The Human Protein } \\
\text { Atlas"; "Tissue expression of } \\
\text { PON2 - Summary - The } \\
\text { Human Protein Atlas"; "Tissue } \\
\text { expression of PON3 - } \\
\text { Summary - The Human Protein } \\
\text { Atlas") }\end{array}$ \\
\hline Protein level & Present in plasma & $\begin{array}{l}\text { Ubiquitous in } \\
\text { occurrence except in } \\
\text { blood }\end{array}$ & $\begin{array}{l}\text { Present in hepatocytes } \\
\text { mainly }\end{array}$ & \\
\hline Enzyme & $\mathrm{EC} \mathrm{3.1.1.2}$ & EC 3.1.1.2 & EC 3.1.1.2 & (“PON1 paraoxonase 1 [Homo \\
\hline classification & EC 3.1.1.81 & EC 3.1.1.81 & EC 3.1.1.81 & sapiens (human)] - Gene - \\
\hline & EC 3.1.8.1 & & EC 3.1.8.1 & $\begin{array}{l}\text { NCBI"; "PON2 paraoxonase } 2 \\
\text { [Homo sapiens (human)] - } \\
\text { Gene - NCBI"; “PON3 } \\
\text { paraoxonase } 3 \text { [Homo sapiens } \\
\text { (human)] - Gene - NCBI") }\end{array}$ \\
\hline \multicolumn{5}{|c|}{ Functions/enzyme activity } \\
\hline Paraoxonase & Significant & Not detected & Not detected & $\begin{array}{l}\text { Draganov et al. (2005), Costa } \\
\text { et al. (2014) }\end{array}$ \\
\hline Arylesterase & $\begin{array}{l}\text { Higher than PON2 } \\
\text { and PON3 }\end{array}$ & Present & Present & \\
\hline Lactonase & Present & $\begin{array}{l}\text { Higher than PON1 } \\
\text { and PON3 }\end{array}$ & Present & \\
\hline Statinase & Not detected & Not detected & Significant & \\
\hline \multicolumn{5}{|c|}{ Pathophysiological association } \\
\hline \multirow[t]{2}{*}{ Atherosclerosis } & $\begin{array}{l}\text { Prevention of HDL } \\
\text { and LDL oxidation }\end{array}$ & $\begin{array}{l}\text { PON2 can inhibit } \\
\text { HDL and LDL } \\
\text { oxidation mainly by } \\
\text { reducing ROS } \\
\text { production }\end{array}$ & $\begin{array}{l}\text { PON3 can also inhibit } \\
\text { HDL and LDL } \\
\text { oxidation mainly by } \\
\text { reducing ROS } \\
\text { produced }\end{array}$ & $\begin{array}{l}\text { Witte et al. (2012), Mackness } \\
\text { and Mackness (2015) }\end{array}$ \\
\hline & $\begin{array}{l}\text { Reduction of } \\
\text { macrophage, } \\
\text { oxidative stress and } \\
\text { inflammatory } \\
\text { response }\end{array}$ & $\begin{array}{l}\text { Associated with } \\
\text { mitochondrial ETC } \\
\text { helping in } \\
\text { sequestering ROS }\end{array}$ & $\begin{array}{l}\text { Associated with } \\
\text { mitochondrial ETC } \\
\text { helps in sequestering } \\
\text { ROS }\end{array}$ & \\
\hline $\begin{array}{l}\text { Inflammatory } \\
\text { diseases }\end{array}$ & $\begin{array}{l}\text { Anti-inflammatory } \\
\text { properties }\end{array}$ & $\begin{array}{l}\text { Antagonizes } \\
\text { inflammatory } \\
\text { processes }\end{array}$ & $\begin{array}{l}\text { Anti-inflammatory } \\
\text { function }\end{array}$ & Devarajan et al. (2014) \\
\hline $\begin{array}{l}\text { Organophosphate } \\
\text { toxicity }\end{array}$ & $\begin{array}{l}\text { Organophosphatase } \\
\text { activity }\end{array}$ & $\begin{array}{l}\text { No } \\
\text { organophosphatase } \\
\text { activity }\end{array}$ & $\begin{array}{l}\text { Only against } \\
\text { paraoxon }\end{array}$ & $\begin{array}{l}\text { Draganov et al. (2005), Gupta } \\
\text { et al. (2011) }\end{array}$ \\
\hline Cancer & $\begin{array}{l}\text { Lower activity of } \\
\text { serum PON1 in } \\
\text { cancer patients }\end{array}$ & $\begin{array}{l}\text { Overexpression in } \\
\text { cancer cells }\end{array}$ & $\begin{array}{l}\text { Overexpression in } \\
\text { cancer cells }\end{array}$ & Bacchetti et al. (2017) \\
\hline
\end{tabular}


Table 1. (continued)

\begin{tabular}{|c|c|c|c|c|}
\hline & PON1 & PON2 & PON3 & References \\
\hline $\begin{array}{l}\text { Quorum quenching } \\
\text { (infectious disease) }\end{array}$ & $\begin{array}{l}\text { Lactonase activity helps in } \\
\text { quorum quenching }\end{array}$ & Highest lactonase activity & $\begin{array}{l}\text { Inactivate acyl-homoserine } \\
\text { lactones }\end{array}$ & $\begin{array}{l}\text { Camps } \\
\text { et al. } \\
\text { (2011) }\end{array}$ \\
\hline Ageing & $\begin{array}{l}\text { Antioxidant, lower level of } \\
\text { expression in elderly }\end{array}$ & $\begin{array}{l}\text { Antioxidant, lower level of } \\
\text { expression in elderly }\end{array}$ & $\begin{array}{l}\text { Antioxidant, lower level of } \\
\text { expression in elderly }\end{array}$ & $\begin{array}{l}\text { Levy et al. } \\
(2019)\end{array}$ \\
\hline
\end{tabular}

paraoxonase but PON2 and PON3 have almost no paraoxonase activity (Draganov et al. 2005). Only PON1 has a weak paraoxonase activity, but all the three PONs exhibit anti-oxidant and anti-inflammatory activities. Their physiological function(s) and native substrates, however, remain ambiguous (Richter et al. 2009; Grdic Rajkovic et al. 2011). The native enzyme activity of paraoxonases was found to be lactonase, suggesting that despite its promiscuous nature the endogenous substrates of paraoxonases are lactones (Draganov et al. 2005).

Subcellular localization studies of PON2 show that it is particularly present at the perinuclear region, endoplasmic reticulum (ER), and mitochondria (Horke et al. 2007). At the plasma membrane level, PON2 is a transmembrane protein with its enzymatic domain facing the extracellular compartment, and thus plays an important role in rescuing peroxidation of membrane components (Hagmann et al. 2014). Mitochondria are cytoplasmic organelles whose integrity is essential for maintaining specific physiological, biochemical, and morphological features of cells. They, therefore, play an essential role in the life and death of the cells (Rasheed et al. 2017). The fact that PON2 is located in mitochondria suggests its anti-oxidative nature, and thus its cytoprotective role. Therefore, PON2 deficiency causes mitochondrial dysfunction in these cells (Devarajan et al. 2011). In addition to its antioxidant activity, PON2 has a remarkably high lactonase activity as compared to PON1 and PON3 (Teiber et al. 2008). The lactonase activity of PON2 may be responsible for its anti-inflammatory role. It was reported in the intestinal epithelial cells that PON2 silencing exacerbated inflammatory processes thereby disturbing the mucosal integrity (Précourt et al. 2012). However, a mutant PON2 (PON2-Asn254Ala/Asn323Ala) lacking lactonase activity does not affect the anti-inflammatory functions (Stoltz et al. 2009). In vivo studies also suggest that PON2 knocked out mice has exacerbated macrophage inflammatory response ( $\mathrm{Ng}$ et al. 2006). The mechanism by which PON2 accomplishes anti-inflammatory function is poorly understood mainly due to the lack of its targets or substrates in physiological conditions.

Association of PON2 with coenzyme Q and preventing reactive oxygen species (ROS) generation in mitochondria is irrespective of its lactonase activity (Altenhöfer et al. 2010; Devarajan et al. 2014). These observations suggest that the antioxidative nature of PON2 might be independent of its lactonase activity. PON1 has been well studied as compared to PON2 and PON3, and recently evolved for the stereospecific hydrolysis of G-type of nerve agents (Gupta et al. 2011). However, PON2 is emerging as an important defense system owing to its location, expression, and significant lactonase activity. The protective role of PON2 has been well documented in vascular, neuronal, macrophage, and other cells against oxidative stress as the downregulation of PON2 was found to be antagonizing its protective effect (Schweikert et al. 2012b). Reportedly, PON2 overexpression prevents ER and/or oxidative stress (Horke et al. 2007). Several chronic diseases develop due to elevated levels of ROS. Therefore, understanding the role of PON2 in scavenging cellular ROS can be an important finding. Although, the cytoprotective role of PON2 is well established, the mechanism by which it reduces ROS and thereby apoptosis, is not well understood (Witte et al. 2012). Therefore, efforts are being made to understand the associated signaling pathways and their pathophysiological relevance (Devarajan et al. 2018).

It would be of many benefits to studying PON2 overexpression and its contribution to cancer as it confers apoptosis resistance (Horke et al. 2008; Witte et al. 2011). Moreover, PON2 is attracting significant interest due to its expression in the nervous system and its role in preventing neurodegeneration (Giordano et al. 2011). Here, we have described the enigmatic role of PON2 in molecular physiology and redox 
homeostasis, and how the modulation of its expression could be a therapy for several diseases.

\section{Regulation of PON2 expression}

Owing to the pathophysiological role of PON2 in several diseases, strategies attempting to modulate its level of expression could have important health implications. In this regard, several bioactive molecules are known to regulate PON2 expression and activity, which are discussed below in details.

\subsection{Transcription factors}

PON2 gene transcription is regulated in an integrated multistep pathway. PON2 expression is under genetic control and regulated by cellular oxidative stress as well as by cholesterol content (Rosenblat et al. 2004; Shiner et al. 2006). Low transcriptional activity of PON2 has been recognized as one of the major culprits in recurrent abortion due to its inadequate antioxidative defense (Dikbas et al. 2018). Several transcription factors such as peroxisome proliferatoractivated receptor $\gamma$ (PPAR $\gamma$ ), sterol regulatory element-binding protein 2(SREBP-2), and activator protein-1 (AP-1) activation are known to upregulate PON2 expression. Reportedly, stimulating macrophages with urokinase activates phosphoinositide 3-kinase (PI3K) through platelet-derived growth factor $\beta$ which further activates NADPH oxidase resulting in the production of ROS, which is ultimately involved in the regulation of PON2 expression (Shiner et al. 2007a, b; Fuhrman et al. 2009). More recently, two new transcription factors, Wilms tumor 1 associated protein (WTAP) and the baculoviral IAP repeat-containing 3 (BIRC3) are shown to modulate PON2 expression and activity (Carusone et al. 2020). Furthermore, it was demonstrated that the glucocorticoidglucocorticoid receptor complexes are directly involved in the transactivation of AP-1 which is responsible for transcriptional activation of the PON2 gene (Shiner et al. 2004, 2007a). Contradictorily, some findings suggest the role of the glucocorticoid receptor in directly regulating PON2 expression irrespective of AP-1 (Lim and Kim 2009). These findings indicate that cellular PON2 expression has a direct or indirect role in signaling pathways associated with ROS production and cholesterol biosynthesis (Fuhrman et al. 2009).
Epigenetic regulation of PON1 has also been established (Huen et al. 2015; Mahrooz et al. 2019); however, the epigenetic regulation of PON2 and PON3 are not studied well (Holland et al. 2015; Mahrooz and Mackness 2020). Xiao et al. showed that PON2 had very little methylation as compared to PON1 and PON3 in case of patients with cerebral infarction and control (Xiao et al. 2019).

\subsection{Hormones}

Hormonal regulation of PON2 has been very-well investigated, where sex steroids have gained much attention (Giordano et al. 2011; Siddiqui et al. 2016). This could be useful to understand the etiology of various neurodegenerative disorders as PON2 levels are higher in central nervous system tissues that is the brain and peripheral region of female mice than male mice (Costa et al. 2014). The lower expression of PON2 in males as compared to females may have wider consequences for the predisposition to oxidative stress diseases. This includes neurodegenerative diseases such as Alzheimer's, Parkinson's, cardiovascular diseases as well as Covid-19, where males are more susceptible to the disease than females (Liguori et al. 2018; Levy et al. 2019; Jin et al. 2020). For example, the incidence of Parkinson's disease is $90 \%$ higher in males as compared to female (Wirdefeldt et al. 2011; Costa et al. 2014), suggesting that the higher PON2 levels in dopaminergic neurons of females may provide better protection against oxidative stress (Giordano et al. 2011, 2013). The gender difference in PON2 expression levels may be attributed to the positive modulatory effect of estrogens in female mice (Leranth et al. 2000; Kitamura et al. 2009; Bwire 2020). Estradiolinduced increase in PON2 mRNA, as well as protein levels, in a time- and concentration-dependent manner, in both male and female striatal astrocytes, is probably due to the activation of estrogen receptoralpha. Similarly, in ovariectomized female mice, it was observed that PON2 mRNA and protein levels decreased as compared to that in a male in brain regions and liver (Cheng and Klaassen 2012; Giordano et al. 2013).

Interestingly, some plant hormones also have a modulatory effect on PON2 expression. Glabridin, the licorice phytoestrogen, has been found to increase PON2 expression, and protects its activity. Glabridin interacts with PON2, and prevents its oxidation, thus 
preserving its activity, in hyperglycemic patients (Yehuda et al. 2011). Furthermore, as PON2 is expressed ubiquitously in all tissues, and the levels of expression is more or less higher in females in each tissues examined, the reported higher sensitivity of males to oxidative stress in the brain, the heart, the kidney, or the liver may be related to the similar mechanism (Klein 2000; Valle et al. 2007).

\subsection{Post-translational modifications (PTMs)}

PTMs take place either on the amino acid side chains or at the $\mathrm{C}$ - or $\mathrm{N}$ - termini of PON2 protein, thereby regulating its catalytic activity. There are contradictory studies on the dependence of PON2 enzyme activity on N-glycosylation. Ser311Cys polymorphism or ubiquitination at Lys 168 have been found to modulate PON2 activity (Mandrich et al. 2015). Amino acid substitution at position 311 from serine to cysteine in recombinant PON2 altered glycosylation, and decreased lactonase activity but protein production and localization are normal (Stoltz et al. 2009). Likewise, studies are pointing to side-chain modification of amino acid residues regulating the catalytic activity of PON2. Carusone et. al. found that $\mathrm{N}$-(3-oxododecanoyl)-L-homoserine lactone (3OC12-HSL) induced post-translational modification at multiple positions in PON2. For instance, posttranslational modification at position 144, nearby two SNPs (A148G and S311C) has been shown to affect PON2 activity (Carusone et al. 2020).

\subsection{Non-steroidal anti-inflammatory drugs (NSAIDs)}

Commonly used NSAIDs are reported to affect PON2 specific lactonase and arylesterase activity. NSAIDs, like diclofenac sodium and tenoxicam, have been tested in vitro, causing a significant decline in lactonase activity (Solmaz Avcrkurt and Korkut 2018). On the other hand, antenatal steroid therapy did not affect PON2 mRNA expression in placentae of unexplained intrauterine growth restricted pregnancies as compared to the non-treated group (Dikbas et al. 2017). It is also hypothesized that increased cholesterol content may be the cause of decreased PON2 expression (Rosenblat et al. 2004). Therefore, hypocholesterolemic drugs may prove to be positive modulators of PON2. One such drug, atorvastatin, has been reported to upregulate
PON2 expression in various cell types (Shiner et al. 2007b).

\subsection{Nutraceuticals}

Dietary factors including flavonoids and polyphenols have long been known to possess antioxidant properties, and modulate intracellular antioxidant enzymes. The underlying molecular mechanisms by which flavonoids may induce PON2 gene expression have not been fully elucidated (Pandey and Rizvi 2009; Costa et al. 2016). Flavonoids from pomegranate are reported to affect the DNA binding activity of the transcription factor AP-1, which is present in the promoter region of the PON2 gene (Shiner et al. 2007a). It is also proposed that increasing concentrations of plant polyphenol, quercetin, in murine macrophages resulted in upregulated PON2 at mRNA as well as protein levels (Boesch-Saadatmandi et al. 2009). PON2 gene is partly regulated by NADPH oxidase, which is a molecular target of quercetin (Shiner et al. 2004).

Chlorogenic acid, a major phenolic compound of Yerba mate, a plant species consumed as traditional tea, could increase the relative expression of PON2 mRNA as well as enzyme activity in vitro in macrophages. On the other hand caffeic acid, a metabolite of chlorogenic acid in the plasma, did not affect PON2 gene expression, but increased its enzyme activity at an appropriate concentration (Monteiro et al. 2007; Fernandes et al. 2012).

Eicosapentaenoic acid (EPA) is a long-chain omega3 polyunsaturated fatty acid that was investigated for its cardioprotective property. EPA administration increased HDL cholesterol, decreased fasting blood sugar, and upregulated PON2 gene expression in patients with type 2 diabetes mellitus (Endo and Arita 2016; Golzari et al. 2019). More recently, higher glucose concentration as compared to physiological levels was found to downregulate PON2. The formation of advanced glycation end products is induced by elevated glucose levels. In human umbilical vein endothelial cells (HUVECs), overexpression of PON2 reduced both the early and the late glycation end products, induced ROS, ER stress, and inflammation (Morresi et al. 2019; Ravi et al. 2020).

Negative modulation of PONs, especially PON1, is also reported for several metals, and vice-versa susceptibility to toxicity and neurotoxicity of metals is affected by different levels of PONs (Costa et al. 2017). Therefore, pharmacological, dietary, lifestyle, 
and environmental factors modulating PON2 could be considered as important factors for the prevention and cure of several diseases. Certain modulators of PON2 are broadly classified and summarized in table 2 .

\section{Role of PON2 in cancer}

Several studies in the recent years have confirmed the overexpression of PON2 in cancerous cells. Reportedly, PON2 could be involved in tumor survival and stress resistance. An elaborate clinical study, conducted on tumor samples taken from more than 10,000 patients with different types of cancer, showed a high expression of PON2 in multiple types of solid tumors, suggesting that overexpression of PON2 in cancer cells causes resistant to chemotherapy and other unfavorable conditions causing malignancy (Shakhparonov et al. 2018). Similarly, overexpression of PON2 in bladder cancer cell lines led to a significant increase in cell proliferation and resistance to oxidative stress (Bacchetti et al. 2017). More recently, a study reported PON2 as an oncogene in gastric cancer, overexpression of which was correlated to tumor diffusion and invasion (Wang et al. 2019). Therefore, it is suggested that PON2 can be used as molecular biomarker for the prognosis of multiple types of cancer (Bacchetti et al. 2021; Campagna et al. 2020).

The fact that PON2 helps in apoptotic escape represents a major clinical complication in cancer biology. However, the distinct regulatory pathways are poorly understood. Both PON2 and PON3 are involved in modulating mitochondrial superoxide anion production and ER stress-induced apoptosis (Bacchetti et al.

Table 2. Summary of some recently studied modulators of PON2

\begin{tabular}{|c|c|c|c|}
\hline Modulators & Regulation & Mode of action & References \\
\hline \multicolumn{4}{|l|}{ Synthetic drugs } \\
\hline Atorvastatin & $\begin{array}{l}\text { Upregulates PON2 mRNA and activity in human } \\
\text { monocyte derived macrophages }\end{array}$ & $\begin{array}{l}\text { Anti-atherogenic } \\
\text { role }\end{array}$ & $\begin{array}{l}\text { Rosenblat et al. (2004), } \\
\text { Ninic et al. (2018) }\end{array}$ \\
\hline Pioglitazone & $\begin{array}{l}\text { Upregulates PON2 protein expression in brain striatum of } \\
\text { mice }\end{array}$ & $\begin{array}{l}\text { Stimulating } \\
\text { effect on } \\
\text { PPAR } \gamma\end{array}$ & Blackburn et al. (2020) \\
\hline $\begin{array}{l}\text { NSAID- } \\
\text { Tenoxicam }\end{array}$ & $\begin{array}{l}\text { Downregulates lactonase as well as arylesterase activity } \\
\text { in-vitro in human monocytic cell line }\end{array}$ & $\begin{array}{l}\text { Inhibitory effect } \\
\text { on PON }\end{array}$ & $\begin{array}{l}\text { Solmaz Avc1kurt and } \\
\text { Korkut (2018) }\end{array}$ \\
\hline $\begin{array}{l}\text { NSAID- } \\
\text { Diclofenac } \\
\text { sodium }\end{array}$ & $\begin{array}{l}\text { Downregulates lactonase activity in-vitro in human } \\
\text { monocytic cell line }\end{array}$ & - & $\begin{array}{l}\text { Solmaz Avc1kurt and } \\
\text { Korkut (2018) }\end{array}$ \\
\hline \multicolumn{4}{|l|}{ Nutraceuticals } \\
\hline Quercetin & $\begin{array}{l}\text { Upregulates PON2 mRNA, protein and lactonase activity } \\
\text { in mouse striatal astrocytes }\end{array}$ & $\begin{array}{l}\text { Activates JNK/ } \\
\text { AP-1 pathway }\end{array}$ & $\begin{array}{l}\text { Boesch-Saadatmandi } \\
\text { et al. (2009), Costa } \\
\text { et al. (2016) }\end{array}$ \\
\hline $\begin{array}{l}\text { Yerba mate } \\
\text { extracts }\end{array}$ & $\begin{array}{l}\text { Upregulates PON2 mRNA and activity in macrophage } \\
\text { and monocyte }\end{array}$ & - & Fernandes et al. (2012) \\
\hline \multicolumn{4}{|l|}{ Hormones } \\
\hline Estrogen & Upregulates PON2 mRNA and protein in mice astrocytes & $\begin{array}{l}\text { Estrogen } \\
\text { receptor }-\alpha\end{array}$ & Giordano et al. (2013) \\
\hline $\begin{array}{l}\text { Human chorionic } \\
\text { gonadotropin }\end{array}$ & $\begin{array}{l}\text { Upregulates PON2 mRNA and protein in human lung } \\
\text { carcinoma cell line }\end{array}$ & $\begin{array}{l}\text { Pro-tumorigenic } \\
\text { role }\end{array}$ & Sahoo et al. (2015) \\
\hline $\begin{array}{l}\text { Phytohormone } \\
\text { (Glabridin) }\end{array}$ & $\begin{array}{l}\text { Upregulates PON2 mRNA, protein and activity in-vitro in } \\
\text { monocytes and in-vivo in hyperglycemic mouse liver } \\
\text { and heart }\end{array}$ & $\begin{array}{l}\text { Anti-atherogenic } \\
\text { effect }\end{array}$ & Yehuda et al. (2011) \\
\hline \multicolumn{4}{|c|}{ Dietary compounds } \\
\hline $\begin{array}{l}\text { Pomegranate } \\
\text { juice }\end{array}$ & $\begin{array}{l}\text { Upregulates PON } 2 \text { mRNA, protein and activity in mouse } \\
\text { macrophage cell line }\end{array}$ & $\begin{array}{l}\text { Activation of } \\
\text { TFs PPAR } \text { PAn }_{\gamma} \text { and } \\
\text { AP-1 }\end{array}$ & Shiner et al. (2007a) \\
\hline $\begin{array}{l}\text { Eicosapentaenoic } \\
\text { acid (EPA)[fish } \\
\text { oil] }\end{array}$ & Upregulates PON2 mRNA & - & Golzari et al. (2019) \\
\hline $\begin{array}{l}\text { Glycation end } \\
\text { products }\end{array}$ & $\begin{array}{l}\text { Downregulates PON2 mRNA, protein expression and } \\
\text { activity in HUVECs }\end{array}$ & - & Ravi et al. (2020) \\
\hline
\end{tabular}


2019). Unfolded protein response (UPR) pathway is a pathway that is activated in response to ER stress, and aims at limiting misfolded proteins accumulation (Walczak et al. 2019). It is hypothesized that ER stress causes protein misfolding leading to the expression of molecular chaperon HSP70 (Bip) in the ER lumen. Bip helps in the dimerization of Protein kinase RNA like Endoplasmic Reticulum Kinase (PERK) leading to C/EBP Homologous Protein (CHOP)-mediated apoptosis (figure 3) (Sato et al. 2000). The antioxidant nature of PON2, and its involvement in the UPR pathway, suggests an endogenous defense mechanism that PON2 may contribute towards the prevention of various diseases (Horke et al. 2008). Overexpression of antioxidant enzymes is not always beneficial. Witte et. al. suggested that PON2 overexpression reduced CHOP expression, and thus apoptosis via the c-Jun N-terminal Kinase (JNK) pathway (Witte et al. 2011).

Another theory put forward for the anti-apoptotic role of PON2 is that p53 transcriptionally represses
PON2, and in case of any mutation in p53, there is overexpression of PON2 (figure 3). PON2 was shown to be overexpressed in pancreatic cancer tissues i.e. pancreatic ductal adenocarcinoma where mutations in TP53 are present which facilitate the metastatic progression (Nagarajan et al. 2017). Along with PON2, other factors like Hypoxia-Inducible Factor-1 (HIF 1) may also come into play, and support tumor progression through multiple pathways (Amelio et al. 2018). It is also reported that PON2 positively modulates the expression of Glucose Transporter 1 (GLUT 1), and thus inhibits the AMP-activated protein kinase (AMPK) pathway (Nagarajan et al. 2017; Pan et al. 2019). AMPK pathway of apoptosis functions in response to cellular starvation in normal cells, and serves as a possible metabolic tumor suppressor ( $\mathrm{Li}$ et al. 2015). As PON2 overexpression causes an increase in GLUT 1 expression, there is more and more glucose intake, which shuts down the AMPK pathway. Therefore, by inhibiting the AMPK pathway PON2

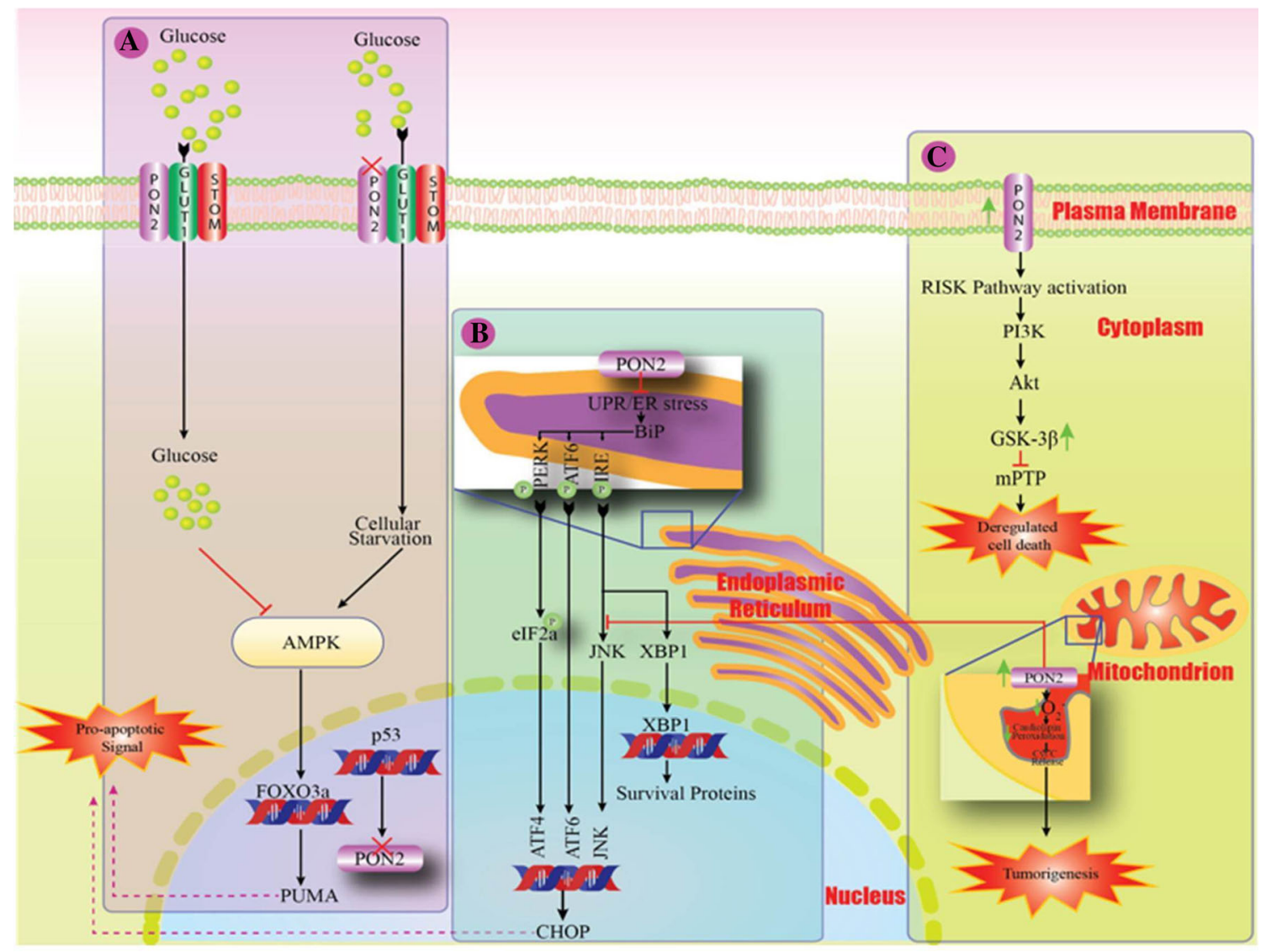

Figure 3. Overview of PON2 and its regulation of different key cell signaling pathways involved in cancer. (A) PON2 expression is transcriptionally regulated by $\mathrm{p} 53$. This in turn regulates glucose uptake by GLUT1 and thus inhibit the AMPK pathway of cell death. (B) Similarly, PON2 inhibits ER stress induced CHOP expression as well as cardiolipin peroxidation and cytochrome $\mathrm{C}$ release in mitochondria, thereby preventing apoptosis. (C) PON2 activates RISK pathway and helps in reducing mitochondrial dysfunction. 
stabilizes the tumor. This is very similar to Warburg's phenomenon suggesting aerobic glycolysis where glucose is used for various biosynthetic pathways that promote cell proliferation (Faubert et al. 2013; Hu et al. 2019). Moreover, PON2 counteracts lipid peroxidation, which may add to stabilizing tumor cells. For example, PON2 attenuates cardiolipin peroxidation in the mitochondrial membrane to prevent intrinsic apoptosis (Witte et al. 2011). In yet another study, regulation of PON2 protein expression through the Wnt/GSK $3 \beta / \beta$-catenin pathway in leukemia and oral squamous cell cancer (OSCC) was demonstrated (Krüger et al. 2016). In OSCC, the anti-apoptotic nature of PON2 was correlated with resistance to radiotherapy (Krüger et al. 2015). PON2 overexpression in bladder cancer cells is also shown to resist chemotherapy by counteracting the induced ROS due to its antioxidative property (Fumarola et al. 2020). In the case of ovarian cancer, it was noticed that PON2 expression was enhanced in the early stages of cancer but at later stages, there was no change in the expression. This might be because PON2 regulates tumorigenesis in a Spatio-temporal manner (Devarajan et al. 2018).

On the other hand, PON2 may also be indirectly involved in tumorigenesis via Reperfusion Injury
Salvage Kinase (RISK) pathway. PON2 reduces cardiolipin peroxidation, cytochrome $\mathrm{C}$ release, and activation of caspase (figure 3) (Sulaiman et al. 2019a, b). Downregulation of PON2 may be important in targeting cancer. According to a report, valproic acid stimulation led to a decrease in PON2 expression in glioblastoma multiforme cells. This in turn inhibited cancer progression by increasing ROS production which ultimately promoted apoptosis via the Bim cascade (Tseng et al. 2017).

\section{Role of PON2 in cardiovascular diseases}

Unlike PON1 and PON3 that remain associated with HDL, and perform an anti-oxidative function, PON2 appears to be present in endothelial cells, smooth muscle cells, and macrophages where it remains associated with membranes of ER and nucleus (Shih and Lusis 2009; She et al. 2012). The cardioprotective role of PON2 is shown in both experimental and human heart failure. This may be attributed to significantly increased PON2 activity, its ability to improve mitochondrial function, and diminish ROS generation ( $\mathrm{Li}$ et al. 2018). Recent studies have shown that in endothelial cells, PON2 prevents

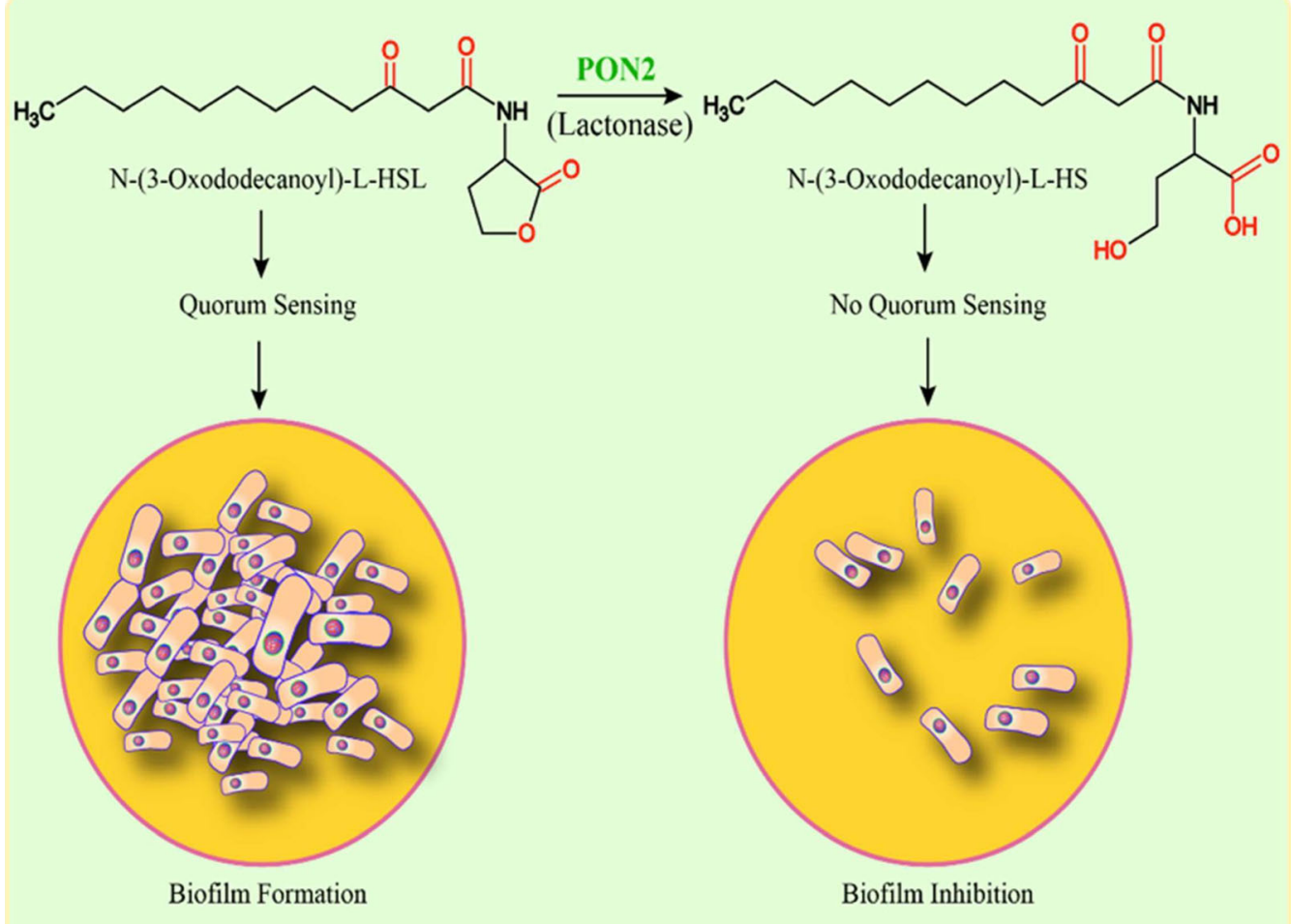

Figure 4. Schematic diagram showing 3OC12-HSL as quorum sensing (QS) molecule which when hydrolyzed by PON2 inhibits biofilm formation. 
systemic coagulation and inflammation by regulating the activity of tissue factors by a redox-dependent mechanism (Ebert et al. 2018). In rats with hemorrhagic shock, it was found that under hypoxic and ischaemic conditions, PON2 regulates the expression of endothelial tissue-related genes such as plasma thrombomodulin transcription factors and endothelial tissue factor activating the mechanism of coagulation (Xu et al. 2020).

Oxidative stress is one of the main causes of atherosclerosis. Hydrolysis of peroxidized lipid is one of the important functions that may contribute to the cardio-protective nature of PON2 (Hagmann et al. 2014). An in vivo study demonstrated that PON2 prevents the oxidation of lipoprotein, thus enhancing the protective capacity of HDL and reducing the intracellular oxidative stress levels of macrophages (Chen et al. 2016). The RISK pathway, PI3K/Akt/ GSK-3 $\beta$ (figure 3C), is cardioprotective against Ischemia-Reperfusion Injury (IRI), PON2 reportedly activates the pathway and therefore prevents mitochondrial dysfunction, and hence oxidative stress in cardiomyocytes (Sulaiman et al. 2019a, b). Apart from cholesterol, triglycerides are also independent risk factors for atherosclerosis, and diacylglycerol acyltransferase 1 (DGAT1) is a rate-limiting enzyme in the triglyceride biosynthetic pathway (Lundberg 1985; Farese et al. 2000). Rosenblat et. al. found that PON2 increases DGAT1 activity, and thus the rate of triglyceride formation. Therefore, one of the mechanisms of the protective role of PON2 in atherosclerosis may be attributed to its regulatory effect on DGAT1 activity which is sensitive to oxidative stress (Rosenblat et al. 2009). But in the case of pro-atherogenic infection, the anti-atherogenic activity of PON2 was attributed to its ability to destroy quorum sensing molecule which is due to the lactonase activity of the enzyme (Kim et al. 2011). The pro-atherogenic infection is contributed by quorum sensing molecules, such as $\mathrm{N}$-(3-oxododecanoyl)-L-homoserine lactone (3OC12-HSL) of Pseudomonas aeruginosa (Turkay et al. 2004).

The role of PON2 was also pointed out in obesity. It was found that PON2 deficient mice had altered mitochondrial function in white adipose tissue which further prevented its conversion to brown adipose tissue, and hence contributed to diet-induced obesity (Shih et al. 2019). A comparative in vivo and in vitro study in type 2 diabetes patients showed a significant decrease in PON2 enzyme activity in monocyte/macrophage cells (Lixandru et al. 2017). It was correlated to abdominal obesity and insulin resistance (Qujeq et al. 2018). However, the underlying molecular mechanisms remain unrecognized.

\section{PON2 and infectious diseases}

Owing to the hydrolytic activity of PON2, it has a crucial role in infectious diseases and associated anomalies such as oxidative stress, inflammation, and changes in the serum proteins (Camps et al. 2017). Studies show that PON2-deficient mice are more prone to bacterial infections than wild-type mice (Stoltz et al. 2007). The role of PON2 in cutaneous defense against bacterial infections due to its high level of expression and activity in human keratinocytes is also reported (Simanski et al. 2012). Most gram-negative bacteria use lactones as quorum sensing (QS) molecules (Rutherford and Bassler 2012). Hydrolytic activity, mainly lactonase activity of PON2, is responsible for the control of QS in gram-negative bacteria such as $P$. aeruginosa, therefore offering an important defense mechanism against bacterial infections (figure 4) (Farid and Horii 2012). PON2 hydrolyzes and inactivates certain homoserine lactones (HSL), and therefore attenuates HSL mediated immune responses (Teiber et al. 2008; Devarajan et al. 2013). Thus, PON2 plays a pivotal role in regulating host cell responses to QS molecules by decreasing their availability for receptor-mediated effects such as calcium release and stress signaling (Horke et al. 2015). The quorum quenching ability of PON2 is also associated with lung pathophysiology of cystic fibrosis (CF) patients. $\mathrm{PPAR}_{\gamma}$ is a mammalian anti-inflammatory transcription factor that is inhibited by 30C12-HSL (Jahoor et al. 2008). Studies suggest that $P$. aeruginosa infected $\mathrm{CF}$ patients have reduced expression of $\operatorname{PPAR}_{\gamma}$ and PON2 genes (Griffin et al. 2012). Therefore, PON2 has been found to play a crucial role in defense against infectious diseases.

Moreover, the role of PON2 in the case of innate immune response to viral infection is also elucidated. In vitro and in vivo studies have shown an increase in PON2 gene expression, protein levels, and activity in response to HIV-1 infection which may be attributed to dephosphorylation of Signal transducer and activator of transcription 5 (STAT5) (Yuan et al., 2010). 


\section{A}
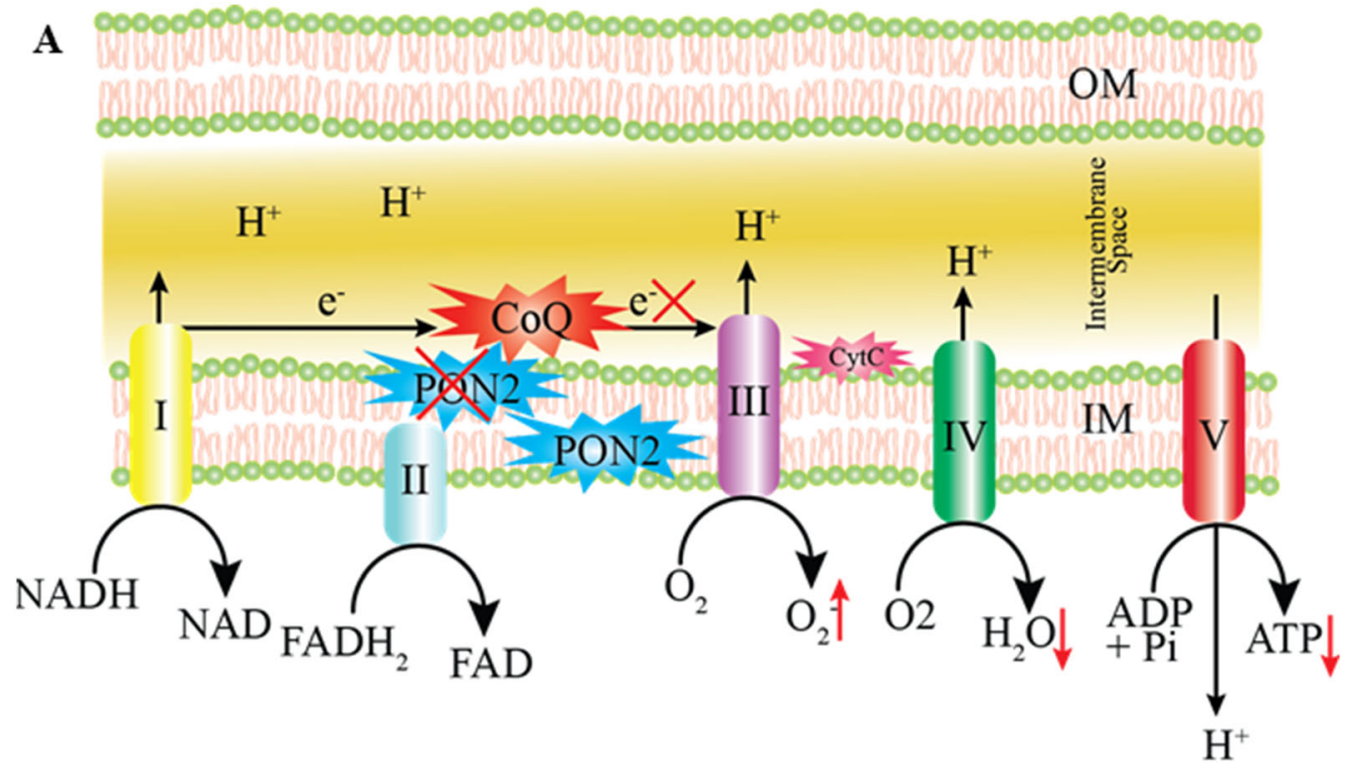

B

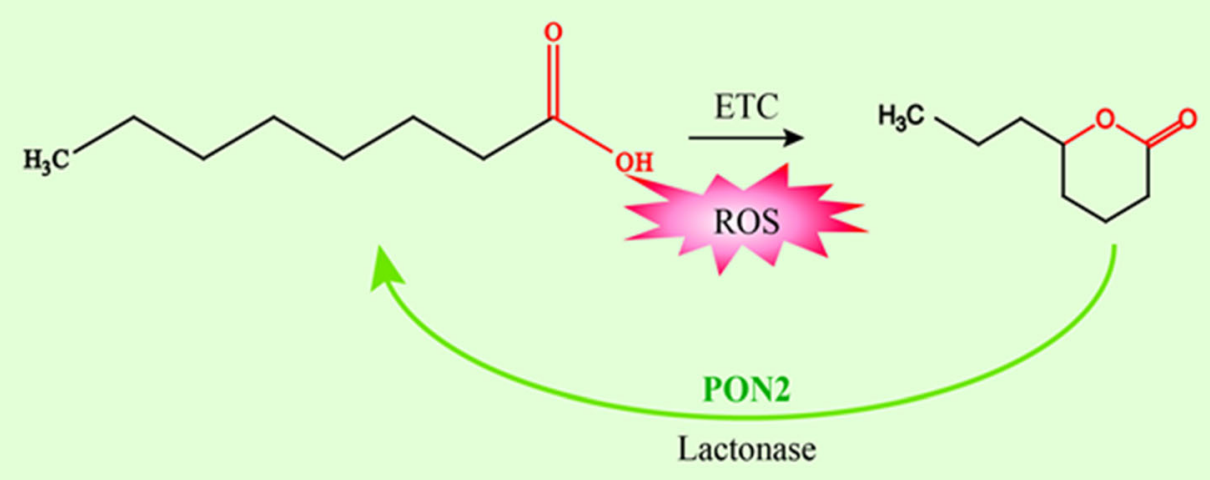

Figure 5. Function of PON2 in mitochondria. (A) Model diagram shows the presence of PON2 protein in the inner mitochondrial membrane. It's association with complex III and coenzyme Q suggests its major role in anti-oxidative function. (B) Flowchart showing the formation of lactone by ROS in the fatty acid chain of plasma membrane and its reversal back to normal by the lactonase activity of PON2.

\section{Role of PON2 in neurodegenerative diseases}

PON2 has been identified as a novel and major intracellular factor with an antagonizing role in oxidative stress in the central nervous system (Costa et al. 2014). It is an intracellular protein, localized on the inner mitochondrial membrane and bound to Coenzyme $\mathrm{Q}_{10}$, a major site for the generation of ROS. PON2 sequesters unstable coenzyme $\mathrm{Q}$ during the $\mathrm{Q}$ cycle and prevents it from passing electrons to oxygen molecules instead of cytochrome C. Its absence or deficiency causes redox imbalance and reduced electron transport activity. It may thus contribute to mitochondrial dysfunction and various oxidative stress disorders (figure 5A) (Devarajan et al. 2011; Enriquez and Lenaz 2014).
Dopaminergic regions of the brain have the highest levels of PON2. There is also evidence that suggests the expression of PON2 is higher in astrocytes than in neurons (Giordano et al. 2011). In an experiment on the study of PON2 levels in the brain during development, the highest expression levels were detected in premature mice with a gradual decline in aged mice. The authors attributed significantly high levels of PON2 in early brain development to its role in protecting brain cells from oxidative stress during the developmental stages (Giordano et al. 2011; Hayashi et al. 2012). Garrick et.al. suggested that lower expression levels of PON2 during the developmental stages, in the brain of neonatal and young adult animals, make them more susceptible to neurological insult by oxidants (Garrick et al. 2016). 
As higher PON2 levels are associated with increased resistance to oxidative stress-induced toxicity and neuroinflammation in brain cells, the possibility of modulating PON2 levels in neuronal cells may represent a much beneficial neuroprotective strategy (Costa et al. 2013). Reportedly, quercetin, a plant flavonoid, helps in mitigating ROS in PON2 $2^{+/+}$mice better than in PON2 $2^{-/}$mice and thus has an ameliorating effect on Alzheimer's disease (AD) (Khan et al. 2020). Though, several hypotheses for the neuroprotective mechanism of quercetin have been put forward yet the exact mechanism is elusive. Either the quercetin induces a low level of oxidative stress and induces PON2 expression through JNK/AP-1 pathway or due to its phytoestrogen activity, PON2 expression is induced (Ruotolo et al. 2014; Costa et al. 2016).

The role of PON2 in Parkinson's disease (PD) was speculated recently. A study reports that DJ 1, a gene responsible for $\mathrm{PD}$, interacts with PON2 and is neuroprotective in the PD model (Parsanejad et al. 2014). However, in the case of $\mathrm{MPP}^{+}$(1-methyl-4phenylpyridinium) induced PD model, lovastatin has a neuroprotective function irrespective of PON2 (Aguirre-Vidal et al. 2015). Apparently, the overexpression of PON2 is cytoprotective, however, its implications can be different depending on the type of cells, for instance, PON2 overexpression is neuroprotective, however, in case of tumor cells the cytoprotective nature of PON2 may inhibit apoptosis and help in cancer progression.

\section{PON2 polymorphism and its association with human pathophysiology}

Two common polymorphisms of PON2 are found, Ala/ Gly at position 148 and Ser/Cys at position 311 (Mochizuki et al. 1998). A few studies are present which demonstrate the relationships of these two PON2 polymorphisms with different pathophysiological conditions (table 3) (Shin 2009; Elnoamany et al. 2014). PON2 Ser311Cys polymorphism has been associated with cardiovascular disease (CVD) but there are still controversies regarding it. Some findings claim that Ser at 311 is more at risk of developing CVD, whereas Cys at 311 prevents premature development of CVD (Martinelli et al. 2004; Chen et al. 2016). On the other hand, few studies report that there is not much significant change between these two polymorphic forms (Sanghera et al. 1998). Therefore, more functional studies need to be carried out for PON2 Ser311Cys polymorphism and its relationship with CVD. More
Table 3. PON2 polymorphism and association with human pathophysiology

\begin{tabular}{|c|c|c|}
\hline $\begin{array}{l}\text { PON2 } \\
\text { Polymorphism }\end{array}$ & Pathophysiology & References \\
\hline \multicolumn{3}{|c|}{ Ala/Gly polymorphism at position 148} \\
\hline \multirow[t]{3}{*}{$\begin{array}{l}\text { Gly at } \\
\text { position } 148\end{array}$} & $\begin{array}{l}\text { Diabetic } \\
\text { nephropathy in } \\
\text { type II diabetes }\end{array}$ & Calle et al. (2006) \\
\hline & $\begin{array}{l}\text { Risk of preterm } \\
\text { delivery }\end{array}$ & Chen et al. (2004) \\
\hline & Cataract & Baig et al. (2019) \\
\hline \multicolumn{3}{|c|}{ Ser/Cys polymorphism at position 311} \\
\hline \multirow[t]{4}{*}{$\begin{array}{l}\text { Cys at } \\
\text { position } 311\end{array}$} & $\begin{array}{l}\text { Coronary heart } \\
\text { disease }\end{array}$ & $\begin{array}{l}\text { Robertson et al. } \\
\text { (2003) }\end{array}$ \\
\hline & $\begin{array}{l}\text { Diabetic } \\
\text { nephropathy in } \\
\text { type II diabetes }\end{array}$ & Wang et al. (2013) \\
\hline & $\begin{array}{l}\text { Noise induced } \\
\text { hearing loss }\end{array}$ & $\begin{array}{l}\text { Fortunato et al. } \\
(2004)\end{array}$ \\
\hline & $\begin{array}{l}\text { Risk of preterm } \\
\text { delivery }\end{array}$ & Chen et al. (2004) \\
\hline \multirow[t]{4}{*}{$\begin{array}{l}\text { Ser at position } \\
311\end{array}$} & $\begin{array}{l}\text { Alzheimer's } \\
\text { disease }\end{array}$ & Janka et al. (2002) \\
\hline & Sporadic & Slowik et al. (2006), \\
\hline & $\begin{array}{l}\text { Amyotrophic } \\
\text { Lateral Sclerosis }\end{array}$ & $\begin{array}{l}\text { Valdmanis et al. } \\
(2008)\end{array}$ \\
\hline & $\begin{array}{l}\text { Coronary heart } \\
\text { disease }\end{array}$ & Sanghera et al. (1998) \\
\hline $\begin{array}{l}\text { Gly } 148 \text { and } \\
\text { Ser } 311\end{array}$ & Cataract & Baig et al. (2019) \\
\hline
\end{tabular}

recently, it has been reported that polymorphism at Ser311Cys is responsible for interaction with another gene PPAR ${ }_{\Upsilon}$, and polymorphic forms of both the gene can serve as biomarkers of risk for coronary heart disease (González-Castro et al. 2018).

PON2 Cys311Ser polymorphism is also linked with AD. PON2 311Ser along with another gene apoE4 allele helps in the development of $\mathrm{AD}$ and vascular dementia (Janka et al. 2002; Nie et al. 2017). The Cys allele of Cys311Ser polymorphism is associated with sporadic Amyotrophic Lateral Sclerosis (ALS) (Saeed et al. 2006; Slowik et al. 2006). Valdmanis et. al. conducted a study on French, Canadian and Swedish population, and found that Cys311Ser polymorphism in PON2 was relevant risk factor for the development of ALS irrespective of patients' nationality (Valdmanis et al. 2008). On the other hand Cys311Ser PON2 polymorphism was not associated with ALS in Italian population (Ricci et al. 2011).

Although PON1/3 are not expressed in the brain, polymorphisms in these are associated with 


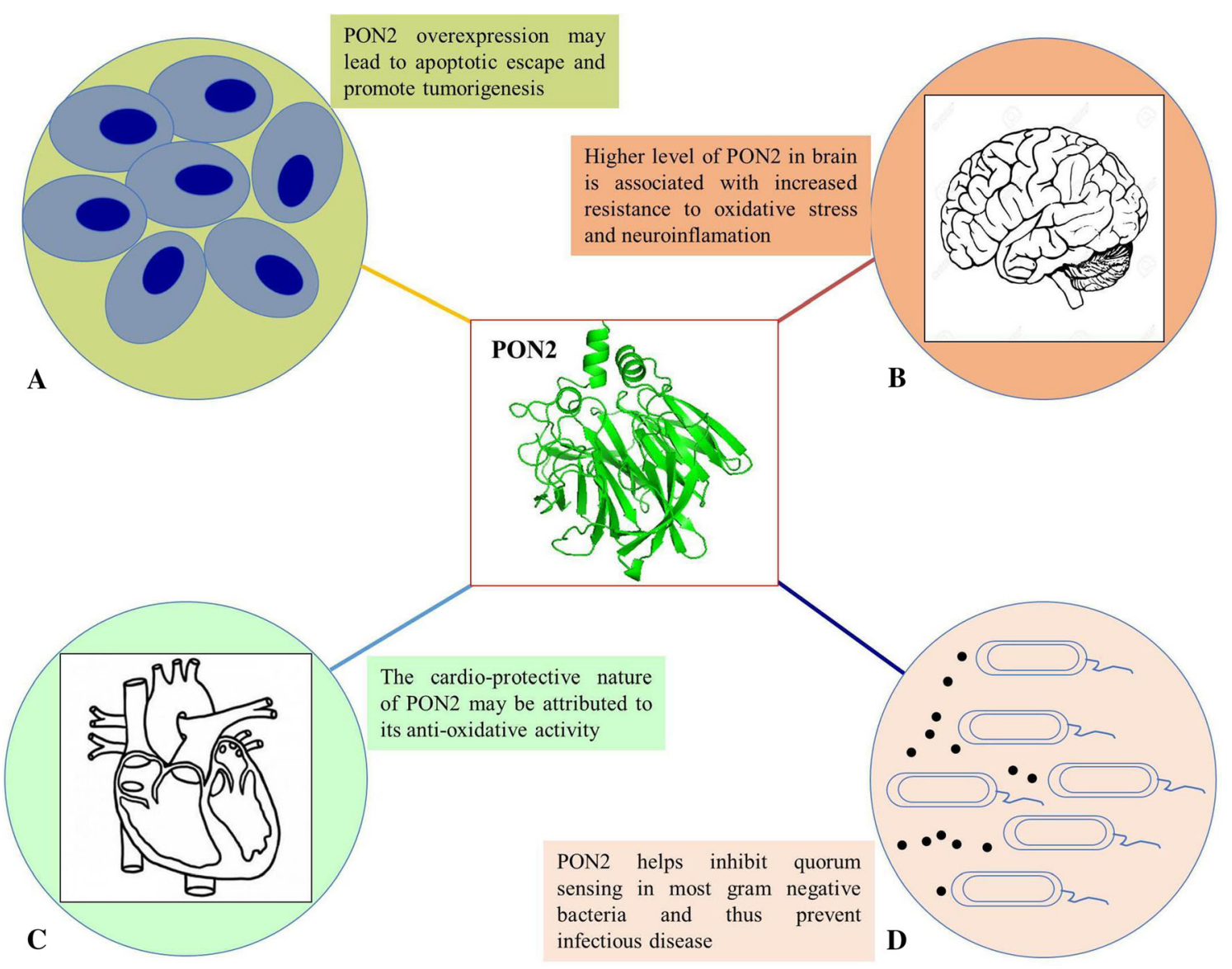

Figure 6. Multifaceted role of PON2. (A) PON2 overexpression is linked to cancer and cell survival, (B) positive modulation of PON2 in brain causing neuroprotection, (C) PON2 deficiency leads to mitochondrial dysfunction, leading to increase in mitochondrial oxidative stress, and (D) highly efficient lactonase activity of PON2 helps in quenching quorum sensing and thus controlling a vast majority of infectious diseases.

neurodegenerative conditions, possibly via regulatory aspects of lipid metabolism (apolipoproteins) (Reichert et al. 2021). Activity and expression level may be associated with PON polymorphism and neurodegeneration. All the PONs can hydrolyze oxidized form of lipids whereas PON1 has in addition organophosphatase activity (Levy et al. 2019). Gene to gene interaction with other polymorphisms across the PON gene family may also be responsible for their neuroprotective nature (Dardiotis et al. 2018). Moreover, ROS may cause the formation of lactone in the fatty acid chain of the plasma membrane. The lactonase activity of PON2 may help in mitigating this change (figure 5b) (Draganov et al. 2005; Hong et al. 2012).

Recently, the association of PON2 polymorphism has been demonstrated in the metabolism of acetylcholinesterase inhibiting drugs (AChEI) such as donepezil hydrochloride and pyridostigmine bromide. The polymorphic forms of PON2, Ala/Gly at position 148 and Ser/Cys at position 311, showed different arylesterase activity, and thus responded differently to these drugs. PON2 with Gly148 and Cys311 allele had increased arylesterase activity, and also the enzyme became more efficient in inhibiting the drug in these cases. The arylesterase activity of PON2 could be responsible for the hydrolysis of AChEI used against $\mathrm{AD}$ and thus attenuating the efficacy of these drugs (Parween et al. 2021).

\section{Conclusions and future perspectives}

PON2 has emerged as an important cellular antioxidant against oxidative stress, mainly due to its expression in several tissues and additionally mitochondrial localization. This lactonase enzyme has shown the potential of being an important biomarker as it plays a relevant role in determining susceptibility to oxidative stress and neuroinflammation. Its overexpression may provide a novel 
strategy for neuroprotection, whereas in tumor cells a useful therapeutic strategy would be helpful in lowering the expression of PON2. A lower rate of occurrence of a wide variety of diseases such as Alzheimer's, Parkinson's, and CVD in females as compared to males suggests that attempts aimed at increasing the PON2 level of expression in males might be useful.

Deciphering the mechanism of PON2 upregulation will also provide useful insights into the pathophysiology of several diseases and thus a therapeutic lead due to its multifaceted role (figure 6). In general, the increase of PON2 activity was associated with gene transcription. The upregulation of PON2 might therefore occur through the stabilization of the PON2 protein or due to its overexpression through an increased translation rate. The kind of cellular signaling pathways that distinct phenolic compounds activate, and the structure and concentration of phenolic compounds themselves also determine the regulation of PON2 activity. Further, understanding the associations of PON2 polymorphism with pathophysiological conditions and drug metabolism would be advantageous for the development of future precision medicines. However, additional studies need to be performed to explain the mechanisms of action of these modulators in the regulation of gene expression and activity.

\section{Acknowledgments}

FP thanks the University Grant Commission, India, for junior research fellowship.

\section{Funding}

RDG thanks DRDO (LSRB-297/BTB/2017) and SERB (EMR/2016/007246), India, for providing financial support.

\section{References}

Aguirre-Vidal Y, Montes S, Tristan-López L, Anaya-Ramos L, Teiber J, Ríos C, Baron-Flores V and Monroy-Noyola A 2015 The neuroprotective effect of lovastatin on MPP+-induced neurotoxicity is not mediated by PON2. Neurotoxicology 48 166-170

Altenhöfer S, Witte I, Teiber JF, Wilgenbus P, Pautz A, Li H, Daiber A, Witan H, et al. 2010 One enzyme, two functions: PON2 prevents mitochondrial superoxide formation and apoptosis independent from its lactonase activity. J. Biol. Chem. 285 24398-24403

Amelio I, Mancini M, Petrova V, Cairns RA, Vikhreva P, Nicolai S, Marini A, Antonov AA, et al. 2018 p53 mutants cooperate with HIF-1 in transcriptional regulation of extracellular matrix components to promote tumor progression. Proc. Natl. Acad. Sci. USA 115 E10869E10878

Bacchetti T, Salvolini E, Pompei V, Campagna R, Molinelli E, Brisigotti V, Togni L, Lucarini G, et al. 2021 Paraoxonase-2: a potential biomarker for skin cancer aggressiveness. Eur. J. Clin. Invest. 5113452

Bacchetti T, Ferretti G and Sahebkar A 2019 The role of paraoxonase in cancer. Semin. Cancer Biol. 56 72-86

Bacchetti T, Sartini D, Pozzi V, Cacciamani T, Ferretti G and Emanuelli M 2017 Exploring the role of Paraoxonase-2 in bladder cancer: analyses performed on tissue samples, urines and cell culturess. Oncotarget 828785

Baig A and Zarina S 2019 Association of PON2 and PON3 polymorphism with risk of developing cataract. Saudi $J$. Ophthalmol. 33 153-158

Blackburn JK, Curry DW, Thomsen AN, Roth RH and Elsworth JD 2020 Pioglitazone activates paraoxonase-2 in the brain: a novel neuroprotective mechanism. Exp. Neurol. 327113234

Boesch-Saadatmandi C, Pospissil RT, Graeser AC, et al. 2009 Effect of quercetin on paraoxonase 2 levels in RAW264. 7 macrophages and in human monocytes-role of quercetin metabolism. Int. J. Mol. Sci. $104168-4177$

Bwire GM 2020 Coronavirus: why men are more vulnerable to Covid-19 than women? SN Compr. Clin. Med. 2 874-876

Calle R, McCarthy MI, Banerjee P, Zeggini E, Cull CA, Thorne KI, Wiltshire S, Terra S, et al. 2006 Paraoxonase 2 (PON2) polymorphisms and development of renal dysfunction in type 2 diabetes: UKPDS 76. Diabetologia 49 2892-2899

Campagna R, Bacchetti T, Salvolini E, Pozzi V, Molinelli E, Brisigotti V, Sartini D, Campanati A, et al. 2020 Paraoxonase-2 silencing enhances sensitivity of A375 melanoma cells to treatment with cisplatin. Antioxidants 9 1238

Camps J, Iftimie S, Garcia-Heredia A, Castro A and Joven J 2017 Paraoxonases and infectious diseases. Clin. Biochem. 50 804-811

Camps J, Pujol I, Ballester F, Joven J and Simó JM 2011 Paraoxonases as potential antibiofilm agents: their relationship with quorum-sensing signals in Gramnegative bacteria. Antimicrob. Agents Chemother. 55 1325-1331

Carusone TM, Cardiero G, Cerreta M, Mandrich L, Moran O, Porzio E, Catara G, Lacerra G, et al. 2020 WTAP and BIRC3 are involved in the posttranscriptional mechanisms that impact on the expression and activity of the human lactonase PON2. Cell Death Dis. 11 1-7 
Chen D, Hu Y, Chen C, Yang F, Fang Z, Wang L and Li J 2004 Polymorphisms of the paraoxonase gene and risk of preterm delivery. Epidemiology 15 466-470

Chen ML, Zhao H, Liao N and Xie ZF 2016 Association between paraoxonase 2 Ser311Cys polymorphism and coronary heart disease risk: a meta-analysis. Med. Sci. Monit. 223196

Cheng X and Klaassen CD 2012 Hormonal and chemical regulation of paraoxonases in mice. J Pharmacol. Exp. Ther. 342 688-695

Costa LG, Cole TB, Garrick JM, Marsillach J and Furlong CE 2017 Metals and paraoxonases. Adv. Neurobiol. 18 $85-111$

Costa LG, Garrick JM, Roquè PJ and Pellacani C 2016 Mechanisms of neuroprotection by quercetin: counteracting oxidative stress and more. Oxid. Med. Cell. Long. 20162986796

Costa LG, de Laat R, Dao K, Pellacani C, Cole TB and Furlong CE 2014 Paraoxonase-2 (PON2) in brain and its potential role in neuroprotection. Neurotoxicology $13-9$

Costa LG, Tait L, de Laat R, Dao K, Giordano G, Pellacani C, Cole TB and Furlong CE 2013 Modulation of paraoxonase 2 (PON2) in mouse brain by the polyphenol quercetin: a mechanism of neuroprotection? Neurochem. Res. 38 1809-1818

Dardiotis E, Siokas V, Sokratous M, Tsouris Z, Michalopoulou A, Andravizou A, Dastamani M, Ralli S, et al. 2018 Genetic polymorphisms in amyotrophic lateral sclerosis: evidence for implication in detoxification pathways of environmental toxicants. Environ. Int. 116 122-135

Devarajan A, Bourquard N, Hama S, Navab M, Grijalva VR, Morvardi S, Clarke CF, Vergnes L, et al. 2011 Paraoxonase 2 deficiency alters mitochondrial function and exacerbates the development of atherosclerosis. Antioxid. Redox Signal. 14 341-351

Devarajan A, Su F, Grijalva V, Yalamanchi M, Yalamanchi A, Gao F, Trost H, Nwokedi J, et al. 2018 Paraoxonase 2 overexpression inhibits tumor development in a mouse model of ovarian cancer. Cell Death Dis. 9 1-6

Devarajan A, Bourquard N, Grijalva VR, Gao F, Ganapathy E, Verma J and Reddy ST 2013 Role of PON2 in innate immune response in an acute infection model. Mol. Genet. Metab. 110 362-370

Devarajan A, Shih D and Reddy ST 2014 Inflammation, infection, cancer and all that the role of paraoxonases. Adv. Exp. Med. Biol. 824 33-41

Dikbas L, Dur R, Tas İH, Yapça ÖE and Dikbas N 2018 Low transcriptional activity of PON2 in recurrent abortion: a novel therapeutic agent? J. Gynecol. Obstet. Hum. Reprod. 47 379-383

Dikbas L, Yapca OE, Dikbas N and Gundogdu C 2017 Paraoxonase-2 and paraoxonase-3: comparison of mRNA expressions in the placentae of unexplained intrauterine growth restricted and noncomplicated pregnancies. $J$. Matern. Neonatal Med. 30 1200-1206
Draganov DI and La Du BN 2004 Pharmacogenetics of paraoxonases: a brief review. Naunyn. Schmiedebergs. Arch. Pharmacol. 369 78-88

Draganov DI, Teiber JF, Speelman A, Osawa Y, Sunahara R and La Du BN 2005 Human paraoxonases (PON1, PON2, and PON3) are lactonases with overlapping and distinct substrate specificities. J. Lipid Res. 46 1239-1247

Ebert J, Wilgenbus P, Teiber JF, Jurk K, Schwierczek K, Döhrmann M, Xia N, Li H, et al. 2018 Paraoxonase-2 regulates coagulation activation through endothelial tissue factor. Blood 131 2161-2172

Elnoamany MF, Dawood AA and Azmy RM 2014 Paraoxonase 2 gene (Cys 311-Ser) polymorphism and the risk of coronary artery disease. World J. Cardiovasc. Dis. 4 465-475

Endo J and Arita M 2016 Cardioprotective mechanism of omega-3 polyunsaturated fatty acids. J. Cardiol. $6722-27$

Enriquez JA and Lenaz G 2014 Coenzyme q and the respiratory chain: coenzyme q pool and mitochondrial supercomplexes. Mol. Syndromol. 5 119-140

Farese RV Jr, Cases S and Smith SJ 2000 Triglyceride synthesis: insights from the cloning of diacylglycerol acyltransferase. Curr. Opin. Lipidol. 11 229-234

Farid AS and Horii Y 2012 Modulation of paraoxonases during infectious diseases and its potential impact on atherosclerosis. Lipids Health Dis. 11 1-5

Faubert B, Boily G, Izreig S, Griss T, Samborska B, Dong Z, Dupuy F, Chambers C, et al. 2013 AMPK is a negative regulator of the Warburg effect and suppresses tumor growth in vivo. Cell Metab. 17 113-124

Fernandes ES, de Oliveira Machado M, Becker AM, de Andrade F, Maraschin M and da Silva EL 2012 Yerba mate (Ilex paraguariensis) enhances the gene modulation and activity of paraoxonase-2: in vitro and in vivo studies. Nutrition 28 1157-1164

Fortunato G, Marciano E, Zarrilli F, Mazzaccara C, Intrieri M, Calcagno G, Vitale DF, La Manna P, et al. 2004 Paraoxonase and superoxide dismutase gene polymorphisms and noise-induced hearing loss. Clin. Chem. 50 2012-2018

Fuhrman B, Gantman A, Khateeb J, Volkova N, Horke S, Kiyan J, Dumler I and Aviram M 2009 Urokinase activates macrophage PON2 gene transcription via the PI3K/ROS/MEK/SREBP-2 signalling cascade mediated by the PDGFR- $\beta$. Cardiovasc. Res. 84 145-154

Fumarola S, Cecati M, Sartini D, Ferretti G, Milanese G, Galosi AB, Pozzi V, Campagna R, et al. 2020 Bladder cancer chemosensitivity is affected by paraoxonase-2 expression. Antioxidants 9175

Garrick JM, Dao K, de Laat R, Elsworth J, Cole TB, Marsillach J, Furlong CE and Costa LG 2016 Developmental expression of paraoxonase 2. Chem. Biol. Interact. 259 168-174

Giordano G, Tait L, Furlong CE, Cole TB, Kavanagh TJ and Costa LG 2013 Gender differences in brain susceptibility 
to oxidative stress are mediated by levels of paraoxonase2 expression. Free Rad. Biol. Med. 58 98-108

Giordano G, Cole TB, Furlong CE and Costa LG 2011 Paraoxonase 2 (PON2) in the mouse central nervous system: a neuroprotective role? Toxicol. Appl. Pharmacol. 256 369-378

Golzari MH, Javanbakht MH, Ghaedi E, Mohammadi H and Djalali M 2019 Effect of eicosapentaenoic acid supplementation on paraoxonase 2 gene expression in patients with type 2 diabetes mellitus: a randomized double-blind clinical trial. Clin. Nutr. Res. 8 17-27

González-Castro TB, Tovilla-Zárate CA, Juárez-Rojop IE, Hernández-Díaz Y, López-Narváez ML, Rodríguez-Pérez C, González-Hernández YK and Ramos-Méndez MA 2018 PON2 and PPARG polymorphisms as biomarkers of risk for coronary heart disease. Biomark. Med. 12 287-297

Grdic Rajkovic M, Rumora L and Barisic K 2011 The paraoxonase 1, 2 and 3 in humans. Biochem. Medica 21 $122-130$

Griffin PE, Roddam LF, Belessis YC, Strachan R, Beggs S, Jaffe A and Cooley MA 2012 Expression of PPAR $\gamma$ and paraoxonase 2 correlated with Pseudomonas aeruginosa infection in cystic fibrosis. PLOS ONE 7 e42241

Gupta RD, Goldsmith M, Ashani Y, Simo Y, Mullokandov G, Bar H, Ben-David M, Leader H, et al. 2011 Directed evolution of hydrolases for prevention of G-type nerve agent intoxication. Nat. Chem. Biol. 7 120-125

Hagmann H, Kuczkowski A, Ruehl M, Lamkemeyer T, Brodesser S, Horke S, Dryer S, Schermer B, et al. 2014 Breaking the chain at the membrane: paraoxonase 2 counteracts lipid peroxidation at the plasma membrane. FASEB J. 28 1769-1779

Hayashi M, Miyata R and Tanuma N 2012 Oxidative stress in developmental brain disorders. Adv. Exp. Med. Biol. 724 278-290

Holland N, Lizarraga D and Huen K 2015 Recent progress in the genetics and epigenetics of paraoxonase: why it is relevant to children's environmental health. Curr. Opin. Pediatr. 27240

Hong KW, Koh CL, Sam CK, Yin WF and Chan KG 2012 Quorum quenching revisited-from signal decays to signalling confusion. Sensors 12 4661-4696

Horke S, Witte I, Wilgenbus P, Altenhöfer S, Krüger M, Li $\mathrm{H}$ and Förstermann U 2008 Protective effect of paraoxonase-2 against endoplasmic reticulum stress-induced apoptosis is lost upon disturbance of calcium homoeostasis. Biochem. J. 416 395-405

Horke S, Witte I, Wilgenbus P, Krüger M, Strand D and Förstermann U 2007 Paraoxonase-2 reduces oxidative stress in vascular cells and decreases endoplasmic reticulum stress-induced caspase activation. Circulation 115 2055-2064

Horke S, Xiao J, Schütz EM, Kramer GL, Wilgenbus P, Witte I, Selbach M and Teiber JF 2015 Novel paraoxonase 2-dependent mechanism mediating the biological effects of the Pseudomonas aeruginosa quorumsensing molecule N-(3-oxo-dodecanoyl)-1-homoserine lactone. Infect. Immun. 83 3369-3380

Hu M, Chen X, Ma L, Ma Y, Li Y, Song H, Xu J, Zhou L, et al. 2019 AMPK inhibition suppresses the malignant phenotype of pancreatic cancer cells in part by attenuating aerobic glycolysis. J. Cancer 10870

Huang Y, Wu Z, Riwanto M, Gao S, Levison BS, Gu X, Fu $\mathrm{X}$, Wagner MA, et al. 2013 Myeloperoxidase, paraoxonase-1, and HDL form a functional ternary complex. $J$. Clin. Invest. 123 3815-3828

Huen K, Yousefi P, Street K, Eskenazi B and Holland N 2015 PON1 as a model for integration of genetic, epigenetic, and expression data on candidate susceptibility genes. Environ. Epigenet. https://doi.org/10.1093/eep/ dvv003

Jahoor A, Patel R, Bryan A, Do C, Krier J, Watters C, Wahli W, Li G, et al. 2008 Peroxisome proliferator-activated receptors mediate host cell proinflammatory responses to Pseudomonas aeruginosa autoinducer. J. Bacteriol. 190 4408-4415

Janka Z, Juhasz A, Rimanoczy A, Boda K, Marki-Zay J and Kalman J 2002 Codon 311 (Cys $\rightarrow$ Ser) polymorphism of paraoxonase-2 gene is associated with apolipoprotein E4 allele in both Alzheimer's and vascular dementias. Mol. Psych. 7 110-112

Jin JM, Bai P, He W, Wu F, Liu XF, Han DM, Liu S and Yang JK 2020 Gender differences in patients with COVID-19: focus on severity and mortality. Front. Public Heal. 8152

Khan H, Ullah H, Aschner M, Cheang WS and Akkol EK 2020 Neuroprotective effects of quercetin in Alzheimer's disease. Biomolecules 1059

Kim JB, Xia YR, Romanoski CE, Lee S, Meng Y, Shi YS, Bourquard N, Gong KW, et al. 2011 Paraoxonase-2 modulates stress response of endothelial cells to oxidized phospholipids and a bacterial quorum-sensing molecule. Arterioscler. Thromb. Vasc. Biol. 31 2624-2633

Kitamura N, Araya R, Kudoh M, Kishida H, Kimura T, Murayama M, Takashima A, Sakamaki Y, et al. 2009 Beneficial effects of estrogen in a mouse model of cerebrovascular insufficiency. PLOS ONE 4 e5159

Klein SL 2000 The effects of hormones on sex differences in infection: from genes to behavior. Neurosci. Biobehav. Rev. 24 627-638

Krüger M, Amort J, Wilgenbus P, Helmstaedter JP, Grechowa I, Ebert J, Tenzer S, Moergel M, et al. 2016 The anti-apoptotic PON2 protein is Wnt/ $\beta$-catenin-regulated and correlates with radiotherapy resistance in OSCC patients. Oncotarget 751082

Krüger M, Pabst AM, Al-Nawas B, Horke S and Moergel M 2015 Paraoxonase-2 (PON2) protects oral squamous cell cancer cells against irradiation-induced apoptosis. $J$. Cancer Res. Clin. Oncol. 141 1757-1766 
Kulka M 2016 A review of paraoxonase 1 properties and diagnostic applications. Pol. J. Vet. Sci. 19 225-232

Leranth C, Roth RH, Elsworth JD, Naftolin F, Horvath TL and Redmond DE 2000 Estrogen is essential for maintaining nigrostriatal dopamine neurons in primates: implications for Parkinson's disease and memory. $J$. Neurosci. 20 8604-8609

Levy D, Reichert CO and Bydlowski SP 2019 Paraoxonases activities and polymorphisms in elderly and old-age diseases: an overview. Antioxidants 8 1-24

Li W, Kennedy D, Shao Z, Wang X, Kamdar AK, Weber M, Mislick K, Kiefer K, et al. 2018 Paraoxonase 2 prevents the development of heart failure. Free Radic. Biol. Med. 121 117-126

Li W, Saud SM, Young MR, Chen G and Hua B 2015 Targeting AMPK for cancer prevention and treatment. Oncotarget 6 7365-7378

Liguori I, Russo G, Curcio F, Bulli G, Aran L, Della-Morte D, Gargiulo G, Testa G, et al. 2018 Oxidative stress, aging, and diseases. Clin. Interv. Aging 13 757-772

Lim J and Kim SH 2009 Transcriptional activation of an anti-oxidant mouse Pon2 gene by dexamethasone. $B M B$ Rep. 42 421-426

Lixandru D, Alexandru P, Mihai A, Roşca A, IonescuTîrgovişte C, Braşoveanu LI and Manuel-y-Keenoy B 2017 Decreased paraoxonase 2 enzymatic activity in monocyte/macrophages cells. A comparative in vivo and in vitro study for diabetes. Free Radic. Res. 51 604-615

Lundberg B 1985 Chemical composition and physical state of lipid deposits in atherosclerosis. Atherosclerosis $\mathbf{5 6}$ 93-110

Mackness M and Mackness B 2015 Human paraoxonase-1 (PON1): gene structure and expression, promiscuous activities and multiple physiological roles. Gene $\mathbf{5 6 7}$ $12-21$

Mahrooz A and Mackness M 2020 Epigenetics of paraoxonases. Curr. Opin. Lipidol. 31 200-205

Mahrooz A, Mackness M, Bagheri A, Ghaffari-Cherati M and Masoumi P 2019 The epigenetic regulation of paraoxonase 1 (PON1) as an important enzyme in HDL function: the missing link between environmental and genetic regulation. Clin. Biochem. 73 1-10

Mandrich L, Cerreta M and Manco G 2015 An engineered version of human PON2 opens the way to understand the role of its post-translational modifications in modulating catalytic activity. PLoS ONE 10 1-20

Marsillach J, Mackness B, Mackness M, Riu F, Beltrán R, Joven J and Camps J 2008 Immunohistochemical analysis of paraoxonases-1, 2, and 3 expression in normal mouse tissues. Free Radic. Biol. Med. 45 146-157

Martinelli N, Girelli D, Olivieri O, Stranieri C, Trabetti E, Pizzolo F, Friso S, Tenuti I, et al. 2004 Interaction between smoking and PON2 Ser311Cys polymorphism as a determinant of the risk of myocardial infarction. Eur. J. Clin. Invest. 34 14-20
Mochizuki H, Scherer SW, Xi T, Nickle DC, Majer M, Huizenga JJ, Tsui LC and Prochazka M 1998 Human PON2 gene at 7q21. 3: cloning, multiple mRNA forms, and missense polymorphisms in the coding sequence. Gene 213 149-157

Monteiro M, Farah A, Perrone D, Trugo LC and Donangelo C 2007 Chlorogenic acid compounds from coffee are differentially absorbed and metabolized in humans. $J$. Nutr. 137 2196-2201

Morresi C, Cianfruglia L, Sartini D, Cecati M, Fumarola S, Emanuelli M, Armeni T, Ferretti G, et al. 2019 Effect of high glucose-induced oxidative stress on paraoxonase 2 expression and activity in Caco-2 cells. Cells 81616

Nagarajan A, Dogra SK, Sun L, Gandotra N, Ho T, Cai G, Cline G, Kumar P, et al. 2017 Paraoxonase 2 facilitates pancreatic cancer growth and metastasis by stimulating GLUT1-mediated glucose transport. Mol. Cell 67 685-701.e6

Ng CJ, Bourquard N, Grijalva V, Hama S, Shih DM, Navab M, Fogelman AM, Lusis AJ, et al. 2006 Paraoxonase-2 deficiency aggravates atherosclerosis in mice despite lower apolipoprotein-B-containing lipoproteins: antiatherogenic role for paraoxonase-2. J. Biol. Chem. 281 29491-29500

Ng CJ, Wadleigh DJ, Gangopadhyay A, Hama S, Grijalva VR, Navab M, Fogelman AM and Reddy ST 2001 Paraoxonase-2 is a ubiquitously expressed protein with antioxidant properties and is capable of preventing cellmediated oxidative modification of low density lipoprotein. J. Biol. Chem. 276 44444-44449

Nie Y, Luo D, Yang M, Wang Y, Xiong L, Gao L, Liu Y and Liu H 2017 A meta-analysis on the relationship of the PON genes and Alzheimer disease. J. Geriatr. Psychiatry Neurol. 30 303-310

Ninic A, Spasojevic-Kalimanovska V and Sopic M, et al. 2018 Paraoxonases gene expression and distribution in rats organs treated with atherogenic diet and atorvastatin therapy http:// nopr.niscair.res.in/handle/123456789/45103

Pan L, Hong C, Xiao G, Geng H, Wang S and Müschen M 2019 Paraoxonase 2 enables initiation of B-ALL by subverting metabolic gatekeeper functions. Blood $\mathbf{1 3 4}$ 746-746

Pandey KB and Rizvi SI 2009 Plant polyphenols as dietary antioxidants in human health and disease. Oxidative medicine and cellular longevity. Oxid. Med. Cell. Longev. 2 270-278

Parsanejad M, Bourquard N, Qu D, Zhang Y, Huang E, Rousseaux MW, Aleyasin H, Irrcher I, et al. 2014 DJ-1 interacts with and regulates paraoxonase-2, an enzyme critical for neuronal survival in response to oxidative stress. PLoS ONE 9 e106601

Parween F, Hossain MS, Singh K and Gupta RD 2021 Association between human paraoxonase 2 protein and efficacy of acetylcholinesterase inhibiting drugs used against Alzheimer's disease. PLoS ONE 16 e0258879 
PON1 paraoxonase 1 [Homo sapiens (human)] - Gene NCBI https://www.ncbi.nlm.nih.gov/gene/5444

PON2 paraoxonase 2 [Homo sapiens (human)] - Gene NCBI https://www.ncbi.nlm.nih.gov/gene/5445

PON3 paraoxonase 3 [Homo sapiens (human)] - Gene NCBI https://www.ncbi.nlm.nih.gov/gene/5446

Précourt LP, Marcil V, Ntimbane T, Taha R, Lavoie JC, Delvin E, Seidman EG, Beaulieu JF, et al. 2012 Antioxidative properties of paraoxonase 2 in intestinal epithelial cells. Am. J. Physiol. Gastrointest. Liver Physiol. 303 G623-G634

Primo-Parmo SL, Sorenson RC, Teiber J and La Du BN 1996 The human serum paraoxonase/arylesterase gene (PON1) is one member of a multigene family. Genomics 33 498-507

Qujeq D, Mahrooz A, Alizadeh A and Boorank R 2018 Paraoxonase- 2 variants potentially influence insulin resistance, beta-cell function, and their interrelationships with alanine aminotransferase in type 2 diabetes. J. Res. Med. Sci. 23107

Rasheed MZ, Tabassum H and Parvez S 2017 Mitochondrial permeability transition pore: a promising target for the treatment of Parkinson's disease. Protoplasma 254 33-42

Ravi R, Nagaraj NR and Rajesh BS 2020 Effect of advanced glycation end product on paraoxonase 2 expression: its impact on endoplasmic reticulum stress and inflammation in HUVECs. Life Sci. 246117397

Reichert CO, Levy D and Bydlowski SP 2021 Paraoxonase role in human neurodegenerative diseases. Antioxidants $101-26$

Ricci C, Battistini S, Cozzi L, Benigni M, Origone P, Verriello L, Lunetta C, Cereda C, et al. 2011 Lack of association of PON polymorphisms with sporadic ALS in an Italian population. Neurobiol. Aging 32 552-e7

Richter RJ, Jarvik GP and Furlong CE 2009 Paraoxonase 1 (PON1) status and substrate hydrolysis. Toxicol. Appl. Pharmacol. 235 1-9

Robertson KS, Hawe E, Miller GJ, Talmud PJ and Humphries SE 2003 Human paraoxonase gene cluster polymorphisms as predictors of coronary heart disease risk in the prospective Northwick Park Heart study II. Biochim. Biophys. Acta Mol. Basis Dis. 1639 203-212

Rosenblat M, Coleman R, Reddy ST and Aviram M 2009 Paraoxonase 2 attenuates macrophage triglyceride accumulation via inhibition of diacylglycerol acyltransferase 1. J. Lipid Res. $\mathbf{5 0} 870-879$

Rosenblat M, Hayek T, Hussein K and Aviram M 2004 Decreased macrophage paraoxonase 2 expression in patients with hypercholesterolemia is the result of their increased cellular cholesterol content: effect of atorvastatin therapy. Arterioscler. Thromb. Vasc. Biol. 24 $175-80$

Ruotolo R, Calani L, Brighenti F, Crozier A, Ottonello S and Del Rio D 2014 Glucuronidation does not suppress the estrogenic activity of quercetin in yeast and human breast cancer cell model systems. Arch. Biochem. Biophys. 559 $62-67$

Rutherford ST and Bassler BL 2012 Bacterial quorum sensing: its role in virulence and possibilities for its control. Cold Spring Harb. Perspect. Med. 2 a012427

Saeed M, Siddique N, Hung WY, Usacheva E, Liu E, Sufit RL, Heller SL, Haines JL, et al. 2006 Paraoxonase cluster polymorphisms are associated with sporadic ALS. Neurology 67 771-6

Sahoo S, Singh P, Kalha B, Singh O and Pal R 2015 Gonadotropin-mediated chemoresistance: delineation of molecular pathways and targets. BMC Cancer 15 1-4

Sanghera DK, Aston CE, Saha N and Kamboh MI 1998 DNA polymorphisms in two paraoxonase genes (PON1 and PON2) are associated with the risk of coronary heart disease. Am. J. Hum. Genet. 62 36-44

Sato N, Urano F, Leem JY, Kim SH, Li M, Donoviel D, Bernstein A, Lee AS, et al. 2000 Upregulation of BiP and CHOP by the unfolded-protein response is independent of presenilin expression. Nat. Cell Biol. 2 863-870

Schweikert EM, Devarajan A, Witte I, Wilgenbus P, Amort J, Förstermann U, Shabazian A, Grijalva V, et al. 2012a PON3 is upregulated in cancer tissues and protects against mitochondrial superoxide-mediated cell death. Cell Death Differ. 19 1549-1560

Schweikert EM, Amort J, Wilgenbus P, Förstermann U, Teiber JF and Horke S 2012b Paraoxonases-2 and-3 are important defense enzymes against Pseudomonas aeruginosa virulence factors due to their anti-oxidative and antiinflammatory properties. J. Lipids 2012 1-9

Shakhparonov MI, Antipova NV, Shender VO, Shnaider PV, Arapidi GP, Pestov NB and Pavlyukov MS 2018 Expression and intracellular localization of paraoxonase 2 in different types of malignancies. Acta Nat. 10 92-99 She ZG, Chen HZ, Yan Y, Li H and Liu DP 2012 The human paraoxonase gene cluster as a target in the treatment of atherosclerosis. Antioxidants Redox Signal. 16 597-632

Shih DM, Meng Y, Sallam T, Vergnes L, Shu ML, Reue K, Tontonoz P, Fogelman AM, et al. 2019 PON2 deficiency leads to increased susceptibility to diet-induced obesity. Antioxidants 819

Shih DM and Lusis AJ 2009 The roles of PON1 and PON2 in cardiovascular disease and innate immunity. Curr. Opin. Lipidol. 20 288-292

Shin BS 2009 Paraoxonase gene polymorphism in southwestern Korean population. J. Korean Med. Sci. 24 561-566

Shiner M, Fuhrman B and Aviram M 2004 Paraoxonase 2 (PON2) expression is upregulated via a reduced-nicotinamide-adenine-dinucleotide-phosphate (NADPH)-oxidase-dependent mechanism during monocytes differentiation into macrophages. Free Radic. Biol. Med. 37 2052-2063

Shiner M, Fuhrman B and Aviram M 2006 A biphasic U-shape effect of cellular oxidative stress on the 
macrophage anti-oxidant paraoxonase 2 (PON2) enzymatic activity. Biochem. Biophys. Res. Commun. 349 1094-1099

Shiner M, Fuhrman B and Aviram M 2007a Macrophage paraoxonase 2 (PON2) expression is up-regulated by pomegranate juice phenolic anti-oxidants via PPAR $\gamma$ and AP-1 pathway activation. Atherosclerosis 195 313-321

Shiner M, Fuhrman B and Aviram M 2007b Macrophage paraoxonase 2 (PON2) expression is upregulated by unesterified cholesterol through activation of the phosphatidylinositol 3-kinase (PI3K) pathway. Biol. Chem. 388 1353-1358

Siddiqui AN, Siddiqui N, Khan RA, Kalam A, Jabir NR, Kamal MA, Firoz CK and Tabrez S 2016 Neuroprotective role of steroidal sex hormones: an overview. CNS Neurosci. Ther. 22 342-350

Simanski M, Babucke S, Eberl L and Harder J 2012 Paraoxonase 2 acts as a quorum sensing-quenching factor in human keratinocytes. J. Invest. Dermatol. 132 2296-2299

Slowik A, Tomik B, Wolkow PP, Partyka D, Turaj W, Malecki MT, Pera J, Dziedzic T, et al. 2006 Paraoxonase gene polymorphisms and sporadic ALS. Neurology 67 766-770

Solmaz Avcıkurt A and Korkut O 2018 Effect of certain non-steroidal anti-inflammatory drugs on the paraoxonase 2 (PON2) in human monocytic cell line U937. Arch. Physiol. Biochem. 124 378-382

Stoltz DA, Ozer EA, Ng CJ, Yu JM, Reddy ST, Lusis AJ, Bourquard N, Parsek MR, et al. 2007 Paraoxonase-2 deficiency enhances Pseudomonas aeruginosa quorum sensing in murine tracheal epithelia. Am. J. Physiol. Cell. Mol. Physiol. 292 L852-L860

Stoltz DA, Ozer EA, Recker TJ, Estin M, Yang X, Shih DM, Lusis AJ and Zabner J 2009 A common mutation in paraoxonase-2 results in impaired lactonase activity. $J$. Biol. Chem. 284 35564-35571

Sulaiman D, Li J, Devarajan A, Cunningham CM, Li M, Fishbein GA, Fogelman AM, Eghbali M, et al. 2019a Paraoxonase 2 protects against acute myocardial ischemia-reperfusion injury by modulating mitochondrial function and oxidative stress via the PI3K/Akt/ GSK-3 $\beta$ RISK pathway. J. Mol. Cell. Cardiol. 129 154-164

Sulaiman D, Papesh JC, Meriwether D and Reddy ST 2019b The role of paraoxonase 2 (PON2) in mitochondrial membrane phospholipid composition and lipid peroxidation. Circ. Res. 125 A885

Taler-Verčič A, Goličnik M and Bavec A 2020 The structure and function of paraoxonase-1 and its comparison to paraoxonase-2 and-3. Molecules 255980

Teiber JF, Xiao J, Kramer GL, Ogawa S, Ebner C, Wolleb H, Carreira EM, Shih DM, et al. 2018 Identification of biologically active $\delta$-lactone eicosanoids as paraoxonase substrates. Biochem. Biophys. Res. Commun. 505 87-92
Teiber JF, Horke S, Haines DC, Chowdhary PK, Xiao J, Kramer GL, Haley RW and Draganov DI 2008 Dominant role of paraoxonases in inactivation of the Pseudomonas aeruginosa quorum-sensing signal $\mathrm{N}$-(3-oxododecanoyl)L-homoserine lactone. Infect. Immun. 76 2512-2519

Tissue expression of PON1 - Summary - The Human Protein Atlas https://www.proteinatlas.org/ENSG00000005421PON1/tissue

Tissue expression of PON2 - Summary - The Human Protein Atlas https://www.proteinatlas.org/ENSG00000105854PON2/tissue.

Tissue expression of PON3 - Summary - The Human Protein Atlas https://www.proteinatlas.org/ENSG00000105852PON3/tissue

Tseng JH, Chen CY, Chen PC, Hsiao SH, Fan CC, Liang YC and Chen CP 2017 Valproic acid inhibits glioblastoma multiforme cell growth via paraoxonase 2 expression. Oncotarget 8 14666-14679

Turkay C, Saba R, Pahin N, Altunbap H, Özbudak Ö, Akkaya B, Özbilim G, Gölbapý Ý, et al. 2004 Effect of chronic Pseudomonas aeruginosa infection on the development of atherosclerosis in a rat model. Clin. Microbiol. Infect. 10 705-708

Valdmanis PN, Kabashi E, Dyck A, Hince P, Lee J, Dion P, D'Amour M, Souchon F, et al. 2008 Association of paraoxonase gene cluster polymorphisms with ALS in France, Quebec, and Sweden. Neurology 71 514-520

Valle A, Guevara R, Garc Í a-Palmer FJ, Roca P and Oliver J 2007 Sexual dimorphism in liver mitochondrial oxidative capacity is conserved under caloric restriction conditions. Am. J. Physiol. Cell Physiol. 293 C1302-8

Walczak A, Gradzik K, Kabzinski J, Przybylowska-Sygut K and Majsterek I 2019 The role of the ER-induced UPR pathway and the efficacy of its inhibitors and inducers in the inhibition of tumor progression. Oxid. Med. Cell. Longev. 20195729710

Wang J, Yang MM, Rong SS, Ng TK, Li YB and Liu XM 2013 Association of paraoxonase gene polymorphisms with diabetic nephropathy and retinopathy. Mol. Med. Rep. 8 1845-1851

Wang X, Xu G, Zhang J, Wang S, Ji M, Mo L, Zhu M, Li J, et al. 2019 The clinical and prognostic significance of paraoxonase-2 in gastric cancer patients: immunohistochemical analysis. Hum. Cell 32 487-494

Wirdefeldt K, Adami HO, Cole P, Trichopoulos D and Mandel J 2011 Epidemiology and etiology of Parkinson's disease: a review of the evidence. Eur. J. Epidemiol. 26 $1-58$

Witte I, Altenhöfer S, Wilgenbus P, Amort J, Clement AM, Pautz A, Li H, Förstermann U, et al. 2011 Beyond reduction of atherosclerosis: PON2 provides apoptosis resistance and stabilizes tumor cells. Cell Death Dis. 2 $1-12$

Witte I, Foerstermann U, Devarajan A, Reddy ST and Horke S 2012 Protectors or traitors: the roles of PON2 
and PON3 in atherosclerosis and cancer. J. Lipids 2012 $1-12$

Xiao J, Li X, Yuan Q, Zhang S, Qu K, Wu B, Wang Y and Duan S 2019 PON1 hypermethylation and PON3 hypomethylation are associated with risk of cerebral infarction. Curr. Neurovasc. Res. 16 115-22

$\mathrm{Xu} \mathrm{JH}, \mathrm{Lu} \mathrm{SJ}, \mathrm{Wu}$ P, Kong LC, Ning C and Li HY 2020 Molecular mechanism whereby paraoxonase- 2 regulates coagulation activation through endothelial tissue factor in rat haemorrhagic shock model. Int. Wound J. 17735
Yehuda I, Madar Z, Szuchman-Sapir A and Tamir S 2011 Glabridin, a phytoestrogen from licorice root, up-regulates manganese superoxide dismutase, catalase and paraoxonase 2 under glucose stress. Phyther. Res. 25 659-667

Yuan J, Devarajan A, Moya-Castro R, Zhang M, Evans S, Bourquard N, Dias P, Lacout C, et al. 2010 Putative innate immunity of antiatherogenic paraoxanase-2 via STAT5 signal transduction in HIV-1 infection of hematopoietic TF-1 cells and in SCID-hu mice. J. Stem Cells 5 43-48

Corresponding editor: Aurnab Ghose 